\title{
Synthesis of prolines by enantioselective 1,3-dipolar cycloaddition of azomethine ylides and alkenes catalyzed by chiral phosphoramidite-silver(I) complexes
}

\author{
Carmen Nájera, ${ }^{[a]} M^{\mathrm{a}}$ de Gracia Retamosa, ${ }^{[a]}$ María Martín-Rodríguez, ${ }^{[a]}$ José M. Sansano,* ${ }^{\text {[a] }}$ \\ Abel de Cózar, ${ }^{[b]}$ and Fernando P. Cossío ${ }^{\text {fb] }}$
}

Dedicated to Prof. Peter Stanetty on the occasion of his $65^{\text {th }}$ birthday

Keywords: asymmetric catalysis / cycloaddition / azomethine ylides / silver / phosphoramidites

The endo-diastereo and enantioselective 1,3-dipolar cycloaddition of azomethine ylides and electrophilic alkenes is efficiently catalysed by chiral phosphoramidite-silver(I) perchlorate complexes. The reaction allows the presence of different type of substituents in the 1,3-dipole and can be applied to the synthesis of enantiomerically enriched highly substituted prolines. This methodology has been applied to the total synthesis of inhibitors of the hepatitis $\mathrm{C}$ virus polymerase.
The computational studies support a two step mechanism predicting exactly the experimental results and the origin of the both diastereo- and enantioselections as well as a rational explanation concerning the different reaction rates observed for some substrates.

(C) WILEY-VCH Verlag GmbH \& Co. KGaA, 69451

Weinheim, Germany, 2009)

\section{Introduction}

The catalytic enantioselective 1,3-dipolar cycloaddition (1,3DC), ${ }^{[1]}$ involving azomethine ylides and electrophilic alkenes, constitutes a straightforward transformation ${ }^{[2]}$ in the generation of up to four stereogenic centres in only one step. The high diastereoand enantioselective control allows to obtain enantiomerically substituted proline derivatives, ${ }^{[3]}$ which are important structures in scientific areas such as biology (peptide design), ${ }^{[3,4]}$ medicine (antiviral, ${ }^{[5]}$ neuroexcitatory, ${ }^{[6]}$ and insecticide agents ${ }^{[7]}$ ) and organic chemistry (organocatalysts). ${ }^{[8]}$

Grigg et al. pioneered the catalytic enantioselective 1,3-DC employing large amounts of chiral cobalt complexes. ${ }^{9}$ In 2002 , the enantioselective synthesis of this enantiomerically pure prolines through the 1,3-DC between azomethine ylides and electrondeficient alkenes was successfully achieved employing a chiral bisphosphine-silver(I) complexes in substoichiometric amounts. ${ }^{[10]}$ Later on many other contributions regarding the employment of the chiral complexes formed by silver(I), ${ }^{[10,11]} \operatorname{copper}(\mathrm{I}),{ }^{[12]} \mathrm{zinc}(\mathrm{II}),{ }^{[13]}$

[a] Prof. C. Nájera, Dr. M. G. Retamosa, M. Martin-Rodríguez and Dr. J. M. Sansano

Departmento de Química Orgánica (Facultad de Ciencias) and Instituto de Síntesis Orgánica (ISO).

Universidad de Alicante

Ctra. Alicante-San Vicente s/n, 03080-Alicante (Spain)

Fax: $(+)+34-9653549$

E-mail: cnajera@ua.es,jmsansano@ua.es

[b] Prof. F. P. Cossío and Dr. A. de Cózar.

Department of Organic Chemistry I

University of the País Vasco-Euskal Herriko Unibertsitatea, P. K. 1072, E-20018 San Sebastián-Donostia (Spain)

\# For correspondence on computational studies: fpcossio@ehu.es

Supporting information for this article is available on the WWW
nickel(II), ${ }^{[14]}$ and calcium(II) ${ }^{[15}$ ] were reported. Recently, organocatalyzed processes ${ }^{[16]}$ has been employed but finding notable structural restrictions, for instance, they need very activated imino-malonates as 1,3-dipole precursors, and $\alpha, \beta$ unsaturated aldehydes or ketones as dipolarophiles.

Silver and copper complexes are the most employed catalysts generating excellent enantioselections in the resulting proline derivatives. Whilst a chiral copper(I)-catalyzed process occurs with high exo-diastereoselection, the silver(I)-catalyzed reaction gave the corresponding endo-adducts. In general, chiral bidentate ligands such as diphosphines, aminophosphines, sulfur-containing phosphines, bisoxazolines and diimines are used as chiral ligand. A common problem in these reactions is their sensitivity to the presence of very bulky substituents in the 1,3-dipole and in the dipolarophile as well.

In a previous communication ${ }^{[11 \mathrm{c}]}$ we reported the first enantioselective 1,3-DC of azomethine ylides and alkenes using monodentate ligands such as chiral phosphoramidites together to $\mathrm{AgClO}_{4}$. The main advantages of this type of catalysts is its availability, the easy modulation of the two stereogenic elements of the chiral ligand, and the use of $\alpha$-branched imino esters. All these aspects are combined to obtain high enantioselectivities of the resulting pyrrolidines. In this work we describe the full account of this reaction, and a DFT-based study focused on the elucidation of the origin of regio-, diastereo- and enantioselectivity observed in the process. ${ }^{[17]}$

\section{Results and Discussion}

Although chiral phosphoramidites $\mathbf{1}, \mathbf{2}$, and $\mathbf{3}^{[18]}$ (Figure 1) have been extensively used in asymmetric hydrogenation ${ }^{[19]}$ and many other transformations such as allylations, Michael-type additions, and carbonyl addition reactions, ${ }^{[19 \mathrm{~b}]}$ they were not previously used as ligands in 1,3-DC between azomethine ylides and dipolarophiles. 


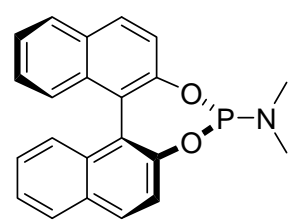

$\left(S_{a}\right)$-Monophos 1<smiles>C[C@H](c1ccccc1)N(C)P(Oc1ccccc1)Oc1ccc2ccccc2c1-c1cccc2ccccc12</smiles>

$\left(S_{a}, R\right)-2$<smiles>C[C@@H](c1ccccc1)P(Oc1ccc2ccccc2c1-c1c(O)ccc2ccccc12)Oc1ccc2ccccc2c1-c1c(OP(c2ccccc2)[C@H](c2ccccc2)N([C@H](C)c2ccccc2)[C@H](C)c2ccccc2)ccc2ccccc12</smiles>

$\left(S_{a}, S, S\right)-3$

$\left(R_{\mathrm{a}}, R, R\right)-3$<smiles>C[C@H](c1ccccc1)N([C@H](C)c1ccccc1)P(Oc1ccc2ccccc2c1)c1c(OP(c2ccccc2)c2ccccc2)ccc2ccccc12</smiles>

$\left(S_{a}, R, R\right)-3$

Figure 1. Phosphoramidites 1-3.

Initially, the optimization of the reaction was carried out at room temperature employing tert-butyl acrylate as dipolarophile and methyl or isopropyl $N$-benzylideneimino glycinates $4 \mathbf{a a}$ or $\mathbf{4 a b}$, respectively. Employing 5 mol-\% of catalyst, formed by in situ addition of a 1:1 mixture of phosphoramidite and the silver salt (Scheme 1, and Table 1) was employed in the presence of an organic base (5 mol-\%). The catalysts formed by $\mathrm{AgClO}_{4}(5 \mathrm{~mol}-$ $\%)$ and ligands $\left(S_{\mathrm{a}}\right)-\mathbf{1}$ or $\mathbf{2}(5 \mathrm{~mol}-\%)$ and triethylamine as base (5 mol-\%) gave lower er of cycloadduct 5 aa than with the catalyst system consisting of a $1: 1$ mixture of $\mathrm{AgClO}_{4}(5 \mathrm{~mol}-\%)$ and $\left(S_{\mathrm{a}}, R, R\right)-3$ (5 mol-\%) (Table 1, entries 1-3). When a 2:1 mixture of $\mathrm{AgClO}_{4}:\left(S_{\mathrm{a}}, R, R\right)-3$ (5 mol-\%) was used instead the er was also lower than the result described for the 1:1 mixture (Table 1, entry 4). Other different silver salts such as acetate, triflate, fluoride, or tetrafluoroborate did not improve the enantiomeric ratio generated by $\mathrm{AgClO}_{4}$ (Table 1, entries 5-8).

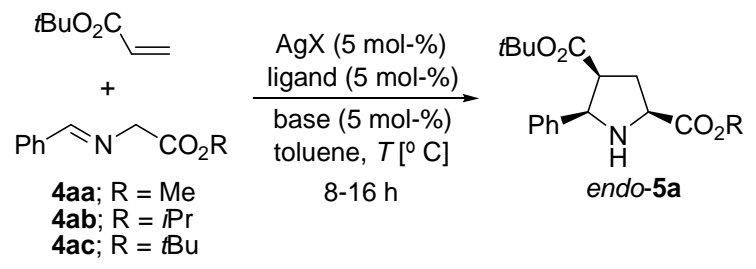

Scheme 1

Then, the temperature, the used base and the ester group nature were studied in order to improve the enantioselectivity of the process. Thus, the reaction of 4 aa run at 0 or at $-20{ }^{\circ} \mathrm{C}$ with $\mathrm{Et}_{3} \mathrm{~N}$ improved the enantioselection (Table 1, compare entries 3,9 and $10)$. Other bases, such as DIPEA or DABCO (5 mol-\%) were also attempted at $-20{ }^{\circ} \mathrm{C}$, obtaining better enantioselections (96:4 er) with DABCO (Table 1, compare entries 10, 12 and 13). Under these conditions monophos ligand $\left(S_{\mathrm{a}}\right) \mathbf{- 1}$ was also employed obtaining lower chiral induction than the reaction done with ligand 3 (Table 1, compare entries 10 and 11). In the other side, the substitution of the methyl by an isopropyl group at the iminoester (Table 1, entries 15-22) was very satisfactory in terms of enantioselection ( $>99: 1)$ and conversions of the product 5ab, when the reaction was performed at $-20{ }^{\circ} \mathrm{C}$ independently of the used base (Table 1 compare entries 10 with 16 and 13 with 17). The best reaction conditions were employed in the reaction of iminoester 4ab with the chiral complex generated from ligand $\left(S_{\mathrm{a}}\right)-\mathbf{1}$, but disappointing results were again achieved (Table 1, compare entries 17 and 18). It was also noticeable that tert-butyl iminoester 4ac $(\mathrm{R}=t \mathrm{Bu})$ were not appropriate as substrates for this particular transformation because the yields, conversions and enantioselectivities were extremely low.

When the enantiomeric ligand $\left(R_{\mathrm{a}}, S, S\right)-\mathbf{3}$ was employed, both iminoesters (4aa, and $\mathbf{4 a b}$ ) afforded at $-20{ }^{\circ} \mathrm{C}$ the corresponding enantiomer of $5 \mathbf{a a}$ and $\mathbf{5 a b}$, respectively (Table 1, entries 14 and $19)$. By contrast, complexes formed by phosphoramidites $\left(R_{\mathrm{a}}, R, R\right)$ 3 or $\left(S_{\mathrm{a}}, S, S\right)-3$ and $\mathrm{AgClO}_{4}$ demonstrated to be mismatched combinations because the reaction of $4 \mathbf{a b}$ and tert-butyl acrylate afforded, in each example, compound ent-5ab with a 28:72 er (Table 1, entries 20 and 21). Smaller amounts of a catalyst loading ( 3 mol-\%) in the reaction at $-20{ }^{\circ} \mathrm{C}$ gave lower yield but similar enantioselectivity of $\mathbf{5 a b}$ (Table 1, entry 22 ).

Other solvents, such as THF, dichloromethane, diethyl ether, acetonitrile, and methanol gave both lower conversions and er values. In all of the examples shown in Tables across the main text, the endo-adduct ${ }^{[20]}$ was obtained as the major stereoisomer with a $d r$ value higher than 98:2 ( ${ }^{1} \mathrm{H}$ NMR). All of the $e r$ data were determined by chiral HPLC analysis, and the absolute configuration was assigned by comparison of the optical rotations between the newly generated products and the reported data for the same compounds. ${ }^{[11]}$

$<<$ Table $1>>$

The new 1:1 and 2:1 complexes of $\mathrm{AgClO}_{4}$ and phosphoramidite $\left(S_{\mathrm{a}}, R, R\right)$-3 were characterised by X-ray crystallographic diffraction of monocrystals. ${ }^{[11 \mathrm{c}]}$ Whilst the $1: 1$ $\left(S_{\mathrm{a}}, R, R\right)-3: \mathrm{AgClO}_{4}$ complex formed cross-linked sheets, the 2:1 mixture afforded well defined crystals. The formation of these polymeric assemblies are typical of silver(I) complexes, independently of the mono- or bidentate character of the corresponding ligand. ${ }^{[21]}$ These complexes are soluble in toluene and could not be recovered from the reaction mixture as in the case of the complex formed by Binap and $\mathrm{AgClO}_{4} \cdot{ }^{[11 b, d]}$

The ESI-MS experiments of the 1:1 and 2:1 $\left(S_{\mathrm{a}}, R, R\right)-3: \mathrm{AgClO}_{4}$ complexes revealed $\mathrm{M}^{+}+1$ peaks at 646 and 1187 , respectively. When an equimolar amounts of the 1,3-dipole precursor 4aa, triethylamine, and a $1: 1$ mixture of $\left(S_{\mathrm{a}}, R, R\right)-3: \mathrm{AgClO}_{4}$ complex were put together, the ESI experiment revealed a very abundant species with $m / z=824$, due to the formation of the chiral silver complex-dipole adduct $\mathbf{I}$ (Figure 2) and a tiny peak at 1000 as a result of the combination of two molecules of dipole to the chiral silver complex. This intermediate complex I was represented also for explaining the both high distereo- and enantioselection offered by the matched combination of the stereochemical elements of ligand $\left(S_{\mathrm{a}}, R, R\right)-\mathbf{3}$. 


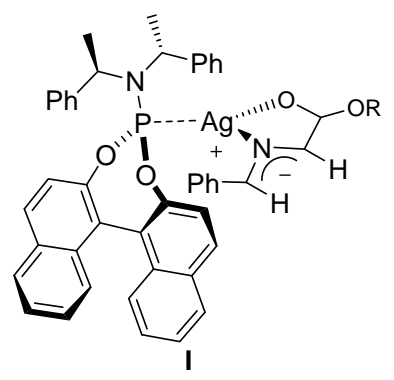

Figure 2. Suggested structure of intermediate complex $\mathbf{I}$

Analogous ${ }^{31} \mathrm{P}$ NMR $\left(\mathrm{CDCl}_{3}, 10\right.$ mol-\% aq. polyphosphoric acid as internal reference) experiments also revealed interesting aspects. Only a wide band centered at $126.9 \mathrm{ppm}$ was observed when a 1:1 mixture of $\left(S_{\mathrm{a}}, R, R\right)-3: \mathrm{AgClO}_{4}$ was formed in solution, which corresponded to its polymeric character detected by X-ray diffraction analysis. However, two separated bands were observed at 124.9 and $132.0 \mathrm{ppm}$ in the case of a 2:1 mixture as a consequence of the partial disaggregation. The almost complete disaggregation of the polymeric sheets of the 1:1 complex was achieved with the addition of 1 equiv. of the 1,3-dipole generate from 4aa and triethylamine. The result was the transformation of the original ${ }^{31} \mathrm{P}$ NMR band into two perfectly defined doublets at $125.1\left(J_{\mathrm{P}-\mathrm{Ag}(109)}=76 \mathrm{~Hz}\right)$ and $133.61 \mathrm{ppm}\left(J_{\mathrm{P}-\mathrm{Ag}(107)}=73 \mathrm{~Hz}\right)$, which, seems to correspond to the phosphorous atom of the complex I.

Due to perchlorates are classified as low order explosives the thermal stability of the $1: 1$ mixture of $\left(S_{\mathrm{a}}, R, R\right)-3: \mathrm{AgClO}_{4}$ complex was studied. The thermogravimetric (TG) and differential thermal analysis (DTA) of this complex (Figure 3) revealed that the loss of water occurred from 50 to $150{ }^{\circ} \mathrm{C}$ without any variation of the heat of the system. The exothermic decomposition of the complex started at $200{ }^{\circ} \mathrm{C}$ approximately, continuing till $600{ }^{\circ} \mathrm{C}$ with a noticeable heat liberation.

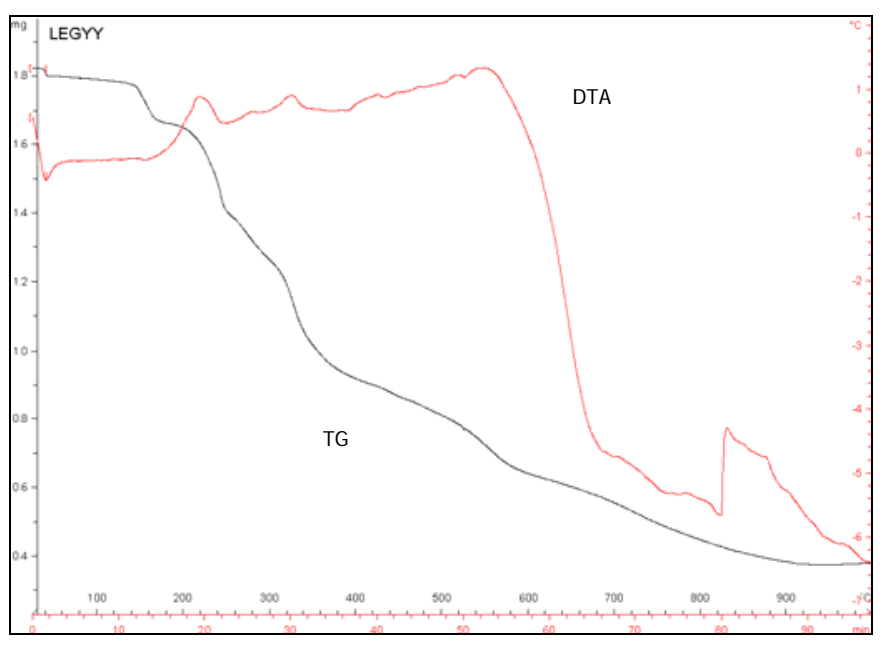

Figure 3. TG and DTA plots of $\left(S_{\mathrm{a}}, R, R\right)-3: \mathrm{AgClO}_{4}$ complex.

Then, the general scope of the enantioselective 1,3-DC of azomethine ylides, generated from iminoesters, with electrophilic alkenes, catalyzed by a $5 \mathrm{~mol}-\%$ of a $1: 1$ mixture of $\left(S_{\mathrm{a}}, R, R\right)$ 3: $\mathrm{AgClO}_{4}$ complex in toluene and in the presence of a base, was studied. Firstly, glycine-derived iminoesters 4 were allowed to react with tert-butyl acrylate under the previously described conditions using triethylamine or DABCO (5 mol-\%) at several temperatures (Scheme 2 and Table 2). The presence of an isopropyl ester in the molecule $\mathbf{4 a b}$, rather than the methyl ester, was very important because the reaction performed at $-20^{\circ} \mathrm{C}$, independently of the used base, afforded endo-cycloadduct $5 \mathbf{a b}$ in good yield (81\%) with a $>99: 1$ er (Table 2, entries 1-4). The ortho-substituted aryl imines $\mathbf{4 b a}$ and $\mathbf{4 c a}$ gave satisfactory results by employing $\mathrm{DABCO}$ as base at $-20^{\circ} \mathrm{C}$. The er of both cycloadducts $5 \mathbf{b a}$ and 5ca was very high after purification (>99:1) (Table 2, entries 5-8). In these last examples the presence of an isopropyl group was not so advantageous as before.

For para-substituted aryl imines, the best results were achieved using $\mathrm{Et}_{3} \mathrm{~N}$ as base at $-20{ }^{\circ} \mathrm{C}$, and isopropyl rather than methyl esters of $\mathrm{N}$-arylideneimino glycinates 4 . The increment in the enantiomeric ratio was very small for the endo-cycloadducts 5da, 5db and 5fa, 5fb (Table 2, entries 9-13 and 18-21, respectively), but was significant for the endo-5eb (99:1 er, Table 2, entries 14-17). The 2-naphthyl derivative 4ga furnished better yields and enantioselections for the methyl esters than the analogous isopropyl esters (not shown in Table 2), using $\mathrm{Et}_{3} \mathrm{~N}$ as base at $-20^{\circ} \mathrm{C}$. The corresponding endo-product 5 ga was obtained in $84 \%$ yield and 96:4 er after flash chromatography (Table 2, entries 22-24).

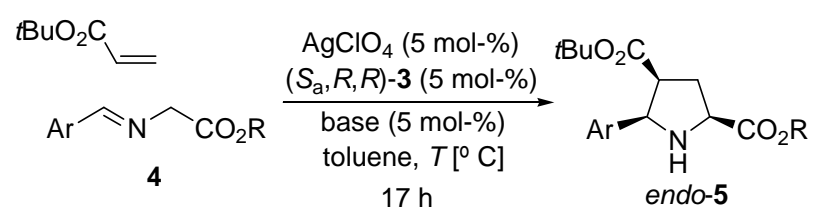

Scheme 2

$<<$ Table $2>>$

Different dipolarophiles were allowed to react with several iminoesters (Scheme 3 and Table 3). Glycine derived iminoesters reacted in very good yields with maleimides at higher temperatures (rt or $0{ }^{\circ} \mathrm{C}$ ) obtaining excellent enantioselectivities of the corresponding cycloadducts 9aa and 10aa (Table 3, entries 1 and 2). Fumarates, chalcone and cyclopent-2-enone were very suitable dipolarophiles employing triethylamine as base at $-20{ }^{\circ} \mathrm{C}$. The yields were in a $72-81 \%$ range and the enantioselections were very important, especially in the examples run with chalcone ( $>99: 1 \mathrm{er})$ (Table 3, entries 3-8).

$\alpha$-Substituted iminoesters derived from alanine, phenylalanine and leucine reacted with tert-butyl acrylate to give endocycloadducts 16-19 in good purified yields and very high enantioselectivities (Table 3, entries 9-15). The best results were always achieved using $\mathrm{Et}_{3} \mathrm{~N}$ as base at $-20{ }^{\circ} \mathrm{C}$ rather than employing DABCO (Table 3, entries 9-15). $N$-Methylmaleimide (NMM) furnished good yields of cycloadducts 20 and 21 and high enantiomeric ratios under the analogous reaction conditions, phenylalanine derivative 7 aa being the less reactive system (Table 3, entries 16-19). Chalcone and (E)-pent-3-enone also reacted with alanine dipole precursors 6aa and 6ga giving good yields of proline derivatives 22aa and 23ga in good yields, with 90:10 and 84:16 er, respectively (Table 3 , entries 20 and 21 ). In all of these examples the presence of isopropyl or tert-buyl esters produced lower enantioselections and very long reaction times. Many of these cycloadducts are known compounds and the comparison of their physical and spectroscopic data obtained and the reported data confirm the absolute configuration represented on each structure. 


$$
\begin{aligned}
& \mathrm{AgClO}_{4}(5 \mathrm{~mol}-\%)
\end{aligned}
$$

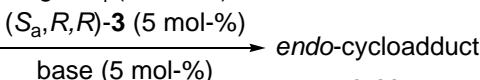

$$
\begin{aligned}
& \text { 4, 6-8 } \\
& + \\
& \text { dipolarophile } \\
& \text { toluene, } 17 \mathrm{~h}, \mathrm{~T}\left[{ }^{\circ} \mathrm{C}\right] \\
& \text { 9-23 }
\end{aligned}
$$

Scheme 3

$<<$ Table $3>>$

It has been demonstrated that enantiomerically pure proline derivative 19ha is the key precursor to a series of antiviral agents inhibitors of the hepatitis $\mathrm{C}$ virus $(\mathrm{HCV})$ polymerase ${ }^{[15 a][16 a][22]}$ such as prolinamide $26 .{ }^{[5 a][23]}$ The intermediate prolinamide 25 was synthesized in $88 \%$ yield (estimated by ${ }^{1} \mathrm{H}$ NMR) from enantiomerically pure $19 \mathrm{ha}$ by a simple amidation reaction with 4 (trifluoromethyl)benzoyl chloride in refluxing dichloromethane during $19 \mathrm{~h}$. The crude product was submitted, in a second step, to a hydrolysis of the tert-butyl ester with trifluoroacetic acid followed by the methyl ester hydrolysis using an aqueous solution of $\mathrm{KOH}$ in methanol for $16 \mathrm{~h}$. The resulting dicarboxylic acid 26 was finally obtained in $81 \%$ yield from compound 25 (50\% overall yield from iminoester 8ha) (Scheme 4). The purity of the antiviral agent was $>98 \%$ and only $0.7 \mathrm{ppm}$ of silver were present in this sample according to inductively coupled plasma mass spectrometry (ICP-MS) analysis. On the basis of this instrumental technique, purified samples of compound 19ha only contained around 4 ppm of silver.

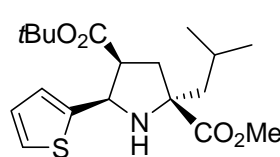

$(2 S, 4 S, 5 R)-19$ ha 91:9 er

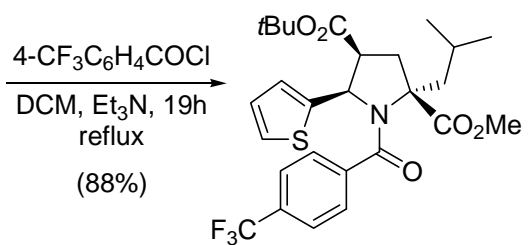

$(2 S, 4 S, 5 R)-25$ 91:9 er

2) $\mathrm{KOH}, \mathrm{MeOH} / \mathrm{H}_{2} \mathrm{O}$ reflux, $20 \mathrm{~h}$<smiles>CC(C)C[C@]1(C(=O)O)C[C@H](C(=O)O)[C@H](c2cccs2)N1C(=O)c1ccc(C(F)(F)F)cc1</smiles>

$(2 S, 4 S, 5 R)-26$ 93:7 er

Scheme 4.

With the aim of getting a better understanding of the origins of the observed stereocontrol we carried out different calculations (see below for technical details) on the interaction modes between $t$-butyl acrylate and the complex II formed by 1,3-dipole precursor 4aa and $\left(S_{\mathrm{a}}\right)$-Monophos 1 . Since we have determined that nonlinear effects have not been observed in these reactions, only monomeric species were considered along the different reaction paths. Our results indicate that the formal [3+2] cycloaddition is actually a stepwise process ${ }^{[24]}$ in which the first step consist of a Michael addition of II on $t$-butyl acrylate. This step determines the stereochemical outcome of the whole reaction. The possible cycloadducts 27 and the corresponding transition structures TS1 that lead to them are depicted in Scheme 5.

$<$ Scheme 5>

Calculations located and characterized the four possible transition structures and their main organic features are gathered in Figure 4. The less energetic saddle points are those that exhibit the $t$-butoxycarboxyl group in an endo relationship with respect to the phenyl group of 4aa. Both TS1-SRR and TS1-RSS lack the highly stabilizing bonding interaction between the $t$-butoxycarbonyl moiety and the metallic centre. As a consequence, these transition structures are $c a .10 \mathrm{kcal} / \mathrm{mol}$ less stable than their endo-analogues.

The two possible endo-TS1 saddle points were much closer in energy (Figure 4). However, TS1-SSR was calculated to be 1.31 $\mathrm{kcal} / \mathrm{mol}$ lower in energy than TS1-RRS. It is observed that the dihedral angle formed by the two naphthyl groups is of $c a$. 57-58 deg. In the case of TS1-SSR, this lead to the blockage of the Re-Si face of the dipole. Since there is a stronger steric congestion between one naphthyl group and the tert-butyl group of the dipolarophile in TS1-RRS (Figure 4). This results, in the preferential formation of the endo- $(2 S, 4 S, 5 R)-27$, were in good agreement with the experimental results.

\section{$<$ Figure 4 $>$}

The reaction coordinate associated with the 1,3-DC between tert-butyl acrylate and complex II to form cycloadduct endo$(2 S, 4 S, 5 R)-27$ is gathered in Figure 5. Reaction between the dipolarophile and complex II results in the formation of complex 28. The computed reaction barrier to form zwiterionic intermediate 29-SSR via TS1-SSR is $c a$. $13 \mathrm{kcal} / \mathrm{mol}$. In this first step complex II and tert-butyl acrylate behave as a silver enolate and a Michael acceptor, respectively. Intermediate 29-SSR cyclises to endo$(2 S, 4 S, 5 R)-27$ via an intramolecular Mannich-like reaction through TS2-SSR with a reaction barrier of $c a .3 \mathrm{kcal} / \mathrm{mol}$. Therefore, the Michael addition reaction determines the stereoselectivity of the stepwise 1,3-DC and it is also the limiting step.

It is interesting to note that endo- $(2 S, 4 S, 5 R)-27$ is $c a$. 5 $\mathrm{kcal} / \mathrm{mol}$ less stable than $\mathbf{2 8}$ because of the strain induced by the coordination pattern around the metallic centre after the complete cyclisation. This ensures the catalyst recovery and the delivery of the endo-NH-cycloadduct 5aa.

$<$ Figure 5 $>$

The simulation of the geometry of intermediate complex II also revealed that a torsion dihedral angle $\left(\mathrm{ca} \mathrm{23^{ \circ } )}\right.$ exists between the imaginary dipole-containing plane and the plane defined by the imine aromatic ring (Figure 6a, see also Figure 4). This detail, $a$ priori insignificant, can seriously affect the reaction rate. It was experimentally observed that the optimised enantioselective reaction of iminoester 8ha (methyl 2-thienyliminoleucinate) and tert-butyl acrylate was completed in $48 \mathrm{~h}$, but the analogous reaction attempted with the iminoester 8aa (methyl phenyliminoleucinate) did not react at all after $48 \mathrm{~h}$. In fact, 2thienyliminoglycinate could not be used as starting material because it reacted with itself (forming the presumed imidazolidine according to ${ }^{1} \mathrm{H} \mathrm{NMR}$ ) rather than with the added dipolarophile, unlike the methyl phenyliminoglycynate 4aa did. This different reactivity can be, presumably, originated by a better hyperconjugation of the enolate in the presence of the thienyl substituent due to the existence of a more planar conformation of the complexes III than in the complex IV. These hypotheses were supported by NOESY experiments performed on complexes III and IV, whose results are depicted in Figure $6 \mathrm{~b}$. The phenyl ring has to rotate in intermediate complex IV, such as it was observed 
in complex II, in order to ensure the interaction of the aromatic $\pi$-electronic current with the silver cation. ${ }^{[25]}$

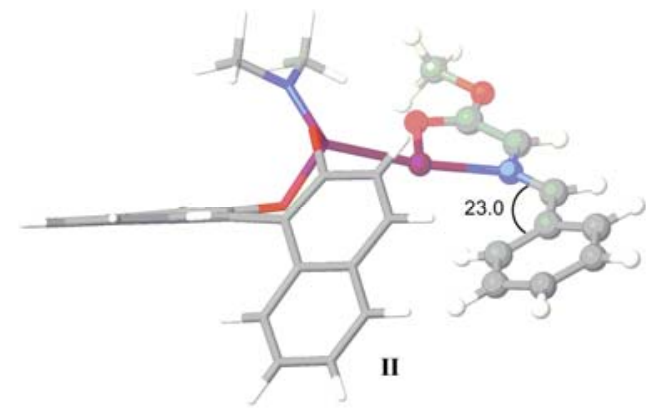

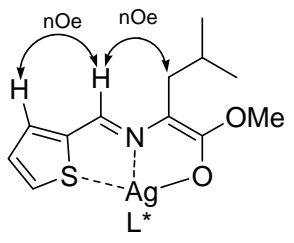

III

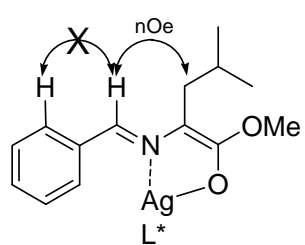

IV

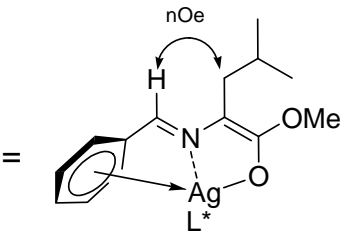

IV
Figure 6. (a) Geometrical features of the complex II. Angles in deg. (b) nOe effects observed in intermediate complexes III and IV.

\section{Conclusions}

The novel equimolar monodentate phosphoramidite $\left(S_{\mathrm{a}}, R, R\right)-3$ silver perchlorate complex is a very efficient chiral catalyst for a wide range of 1,3-dipolar cycloaddition reactions between azomethine ylides and dipolarophiles. This type of monodentate complexes open new perspectives in this and other reactions because is capable to perform cycloadditions involving sterically hindered components, the fine-tuning being achieved by modification of the temperature, base and ester substituent. A direct application of this methodology is the direct synthesis of dicarboxylic acid 26, a very effective agent inhibitor of the HCV polymerase. It was isolated in $50 \%$ overall yield (4 steps) with a 93:7 er. The overall cyclisation process occurred through a nonconcerted reaction, Michael-type addition being the determinant step of the stereochemical outcome of the cyclisation reaction.

\section{Experimental Section}

General. All reactions were carried out in the absence of light. Anhydrous solvents were freshly distilled under an argon atmosphere. Aldehydes were also distilled prior to use for the elaboration of the iminoesters. Melting points were determined with a Reichert Thermovar hot plate apparatus and are uncorrected. Only the structurally most important peaks of the IR spectra (recorded on a Nicolet 510 P-FT) are listed. ${ }^{1} \mathrm{H}$ NMR $(300 \mathrm{MHz})$ and ${ }^{13} \mathrm{C}$ NMR $(75 \mathrm{MHz})$ spectra were obtained on a Bruker AC-300 using $\mathrm{CDCl}_{3}$ as solvent and TMS as internal standard, unless otherwise stated. Optical rotations were measured on a Perkin Elmer 341 polarimeter. HPLC analyses were performed on a JASCO 2000 -series equipped with a chiral column (detailed for each compound in the main text), using mixtures of $n$ hexane/isopropyl alcohol as mobile phase, at $25^{\circ} \mathrm{C}$. Thermal analysis studies were done in TG-DTA METTLER TOLEDO
TGA/SDTA851e/SF/1100. Low-resolution electron impact (EI) mass spectra were obtained at 70eV on a Shimadzu QP-5000 and high-resolution mass spectra were obtained on a Finnigan VG Platform. HRMS (EI) were recorded on a Finnigan MAT 95S. Microanalyses were performed on a Perkin Elmer 2400 and a Carlo Erba EA1108. Analytical TLC was performed on Schleicher \& Schuell F1400/LS silica gel plates and the spots were visualized under UV light $(\lambda=254 \mathrm{~nm})$. For flash chromatography we employed Merck silica gel 60 (0.040-0.063 mm).

Computational methods. All the calculations were obtained with the GAUSSIAN03 suite of programs. ${ }^{[26]}$ Electron correlation was partially taken into account using the hybrid functional $\mathrm{B}^{2} \mathrm{LYP}^{[27]}$ and the standard $6-31 \mathrm{G}^{*}$ basis set ${ }^{28}$ for hydrogen, carbon, oxygen, phosphorous and nitrogen, and the Hay-Wadt small core effective potential (ECP) ${ }^{[29]}$ including double- $\xi$ valence basis $\operatorname{set}^{[30]}$ for silver atoms (LanL2DZ keyword). Zero point vibrational energy (ZPVE) corrections were computed at the B3LYP/LanL2DZ\&6-31G* level and were not scaled. All stationary points were characterized by harmonic analysis. Reactants intermediates and cycloadducts have positive definite Hessian matrices. Transition structures shown only one negative eigenvalue in their diagonalysed force constant matrices, and their associated eigenvectors were confirmed to correspond to the motion along the reaction coordinate under consideration (for more details, see supporting information).

1,3-Dipolar cycloaddition of iminoesters and dipolarophiles. General procedure. A solution of the iminoester $(1 \mathrm{mmol})$ and dipolarophile (1 mmol) in toluene $(5 \mathrm{~mL})$ was added to a suspension containing the phosphoramidite $(0.05 \mathrm{mmol})$ and $\mathrm{AgClO}_{4}(0.05 \mathrm{mmol}, 10 \mathrm{mg})$ in toluene $(5 \mathrm{~mL})$. To the resulting suspension triethylamine $(0.05 \mathrm{mmol}, 7 \mu \mathrm{L})$ was added and the mixture stirred at the temperature indicated in the text and in the absence of the light for 16-48 $\mathrm{h}$. The precipitate was filtered and the organic phase was directly evaporated and the residue was purified by recrystallization or by flash chromatography yielding pure endocycloadducts (see Tables 2 and 3 for details).

4-tert-Butyl 2-methyl $\quad(2 S, 4 S, 5 R)-5$-phenyl-2,4-pyrrolidinodicarboxylate (5aa): ${ }^{[11 \mathrm{j}]}$ (254 mg, 80\%).

4-tert-Butyl 2-isopropyl (2S,4S,5R)-5-phenyl-2,4-pyrrolidinodicarboxylate (5ab): Sticky oil $(276 \mathrm{mg}, 83 \%) ;[\alpha]_{\mathrm{D}}{ }^{20}=+20.1^{\circ} \quad\left(c=0.9, \mathrm{CHCl}_{3}, 99 \%\right.$ ee by HPLC); $R_{\mathrm{f}}$ : 0.46 ( $n$-hexane/ethyl acetate: $\left.3 / 2\right)$; IR $(\mathrm{KBr})$ v. 1727,1705 , $2977 \mathrm{~cm}^{-1} ;{ }^{1} \mathrm{H}$ NMR $\delta_{\mathrm{H}}: 1.03\left[\mathrm{~s}, 9 \mathrm{H}, \mathrm{CO}_{2} \mathrm{C}\left(\mathrm{CH}_{3}\right)_{3}\right], 1.30[\mathrm{~d}, J=6.3 \mathrm{~Hz}, 3 \mathrm{H}$, $\left.\mathrm{CO}_{2} \mathrm{CH}\left(\mathrm{CH}_{3}\right)_{2}\right], 2.26\left(\mathrm{~m}, 1 \mathrm{H}, \mathrm{CH}_{2}\right), 2.44\left(\mathrm{~m}, 1 \mathrm{H}, \mathrm{CH}_{2}\right), 2.69$ (broad s, $1 \mathrm{H}$, $\mathrm{NH}), 3.26\left(\mathrm{~m}, 1 \mathrm{H}, \mathrm{CHCO}_{2} t \mathrm{Bu}\right), 3.89\left(\mathrm{dd}, J=8.4,8.4 \mathrm{~Hz}, 1 \mathrm{H}, \mathrm{CHCO}_{2} i \mathrm{Pr}\right)$, 4.48 (d, $J=7.9 \mathrm{~Hz}, 1 \mathrm{H}, \mathrm{CHPh}), 5.15$ [sept, $J=6.3 \mathrm{~Hz}, 1 \mathrm{H}, \mathrm{CO}_{2} \mathrm{CH}\left(\mathrm{CH}_{3}\right)_{2}$ ], 7.21-7.38 (m, 5H, $\mathrm{ArH}) ;{ }^{13} \mathrm{C}$ NMR $\delta_{\mathrm{C}}: 21.8 \quad\left[\mathrm{CO}_{2} \mathrm{CH}\left(\mathrm{CH}_{3}\right)_{2}\right], 27.4$ $\left[\mathrm{CO}_{2} \mathrm{C}\left(\mathrm{CH}_{3}\right)_{3}\right], 34.3\left(\mathrm{CH}_{2}\right), 50.3\left(\mathrm{CHCO}_{2} t \mathrm{Bu}\right), 60.2\left(\mathrm{CHCO}_{2} i \mathrm{Pr}\right), 65.6$ $\left[\mathrm{CO}_{2} \mathrm{CH}\left(\mathrm{CH}_{3}\right)_{2}\right], 68.6(\mathrm{Ph}-\mathrm{CH}), 80.5\left[\mathrm{CO}_{2} \mathrm{C}\left(\mathrm{CH}_{3}\right)_{3}\right], 127.2,127.3,128.1$ $(\mathrm{ArCH}), 139.5$ (ArC), 171.8, $172.8\left(\mathrm{CO}_{2} i \mathrm{Pr}, \mathrm{CO}_{2} t \mathrm{Bu}\right) ; \mathrm{MS}(\mathrm{EI}) \mathrm{m} / z(\%)$ : $333\left(\mathrm{M}^{+}, 0.78 \%\right), 246$ (47), 205 (12), 191 (13), 190 (100), 172 (13), 163 (11), 145 (12), 144 (31), 117 (22); HRMS calcd. for $\mathrm{C}_{19} \mathrm{H}_{27} \mathrm{NO}_{4}: 333.1940$, found: 333.1929 ; HPLC (column AS, $1 \mathrm{~mL} / \mathrm{min}, n$-hexane $/ i$-PrOH: $99: 1, \lambda$ $220 \mathrm{~nm}), \mathrm{t}_{\mathrm{Rmaj}}=15.3 \mathrm{~min}, \mathrm{t}_{\mathrm{Rmin}}=58.5 \mathrm{~min}$.

4-tert-Butyl 2-methyl (2S,4S,5R)-5-(2-methylphenyl)-2,4pyrrolidinodicarboxylate (5ba): ${ }^{[11 \mathrm{j}]}(276 \mathrm{mg}, 83 \%)$.

4-tert-Butyl 2-methyl (2S,4S,5R)-5-(2-chlorophenyl)-2,4pyrrolidinodicarboxylate (5ca): ${ }^{[11 \mathrm{j}]}(283 \mathrm{mg}, 80 \%)$.

4-tert-Butyl 2-methyl (2S,4S,5R)-5-(4-methylphenyl)-2,4pyrrolidinodicarboxylate (5da): ${ }^{[11 \mathrm{j}]}(260 \mathrm{mg}, 78 \%)$.

4-tert-Butyl 2-isopropyl $\quad(2 S, 4 S, 5 R)-5$-(4-methylphenyl)-2,4 pyrrolidinodicarboxylate (5db): Sticky oil $(278 \mathrm{mg}, 80 \%) ;[\alpha]_{\mathrm{D}}{ }^{20}=+44.1^{\circ}$ ( $c=1, \mathrm{CHCl}_{3}, 99 \%$ ee by HPLC); $R_{\mathrm{f}}: 0.43$ ( $n$-hexane/ethyl acetate: $3 / 2$ ); IR

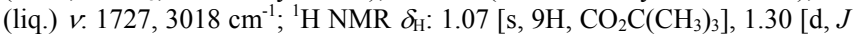
$\left.=6.2 \mathrm{~Hz}, 3 \mathrm{H}, \mathrm{CO}_{2} \mathrm{CH}\left(\mathrm{CH}_{3}\right)_{2}\right], 2.32\left(\mathrm{~s}, 3 \mathrm{H}, \mathrm{PhCH}_{3}\right), 2.50\left(\mathrm{~m}, 1 \mathrm{H}, \mathrm{CH}_{2}\right), 2.44$ $\left(\mathrm{m}, 1 \mathrm{H}, \mathrm{CH}_{2}\right), 3.31\left(\mathrm{dd}, J=13.9,7.7 \mathrm{~Hz}, 1 \mathrm{H}, \mathrm{CHCO}_{2} t \mathrm{Bu}\right), 4.07$ (dd, $J=$ 8.4, $\left.8.2 \mathrm{~Hz}, 1 \mathrm{H}, \mathrm{CHCO}_{2} i \mathrm{Pr}\right), 4.59$ (d, $\left.J=7.8 \mathrm{~Hz}, 1 \mathrm{H}, \mathrm{CHPh}\right), 5.15[\mathrm{~m}, 1 \mathrm{H}$, $\mathrm{CO}_{2} \mathrm{CH}\left(\mathrm{CH}_{3}\right)_{2}$ ], $7.13(\mathrm{~d}, J=8.0 \mathrm{~Hz}, 2 \mathrm{H}, \mathrm{ArH}), 7.23(\mathrm{~d}, J=8.1 \mathrm{~Hz}, 2 \mathrm{H}$, $\mathrm{ArH}) ; \quad{ }^{13} \mathrm{C} \quad \mathrm{NMR} \quad \delta_{\mathrm{C}}: \quad 21.0 \quad\left(\mathrm{ArCH}_{3}\right), 21.7 \quad\left[\begin{array}{ll}\left.\mathrm{CO}_{2} \mathrm{CH}\left(\mathrm{CH}_{3}\right)_{2}\right], & 27.5\end{array}\right.$ $\left[\mathrm{CO}_{2} \mathrm{C}\left(\mathrm{CH}_{3}\right)_{3}\right], 33.6\left(\mathrm{CH}_{2}\right), 51.0\left(\mathrm{CHCO}_{2} t \mathrm{Bu}\right), 59.7\left(\mathrm{CHCO}_{2} i \mathrm{Pr}\right), 65.2$ $\left[\mathrm{CO}_{2} \mathrm{CH}\left(\mathrm{CH}_{3}\right)_{2}\right], 69.6(\mathrm{ArCH}), 81.2\left[\mathrm{CO}_{2} \mathrm{C}\left(\mathrm{CH}_{3}\right)_{3}\right], 127.0,129.1(\mathrm{ArCH})$, 137.5, $137.6(\mathrm{ArC}), 171.4,171.6\left(\mathrm{CO}_{2} i \mathrm{Pr}, \mathrm{CO}_{2} t \mathrm{Bu}\right)$; MS (EI) $\mathrm{m} / z(\%): 347$ $\left(\mathrm{M}^{+}, 1.35 \%\right), 290$ (16), 274 (12), 260 (46), 219 (25), 205 (14), 204 (100), 186 (25), 177 (12), 160 (13), 159 (21), 158 (42), 143 (17), 131 (46), 57 (12), 56 (14); HRMS calcd. for $\mathrm{C}_{20} \mathrm{H}_{29} \mathrm{NO}_{4}$ : 347.2097, found: 347.2102 ; HPLC (column Chiralpak AS, $1 \mathrm{~mL} / \mathrm{min}, n$-hexane $/ i$-PrOH 95:5, $\lambda 220$ $\mathrm{nm}), \mathrm{t}_{\mathrm{Rmaj}}=6.8 \mathrm{~min}, \mathrm{t}_{\mathrm{Rmin}}=18.6 \mathrm{~min}$. 
4-tert-Butyl 2-methyl $\quad(2 S, 4 S, 5 R)-5$-(4-methoxyphenyl)-2,4pyrrolidinodicarboxylate (5ea) ${ }^{[11 \mathrm{j}]}(275 \mathrm{mg}, 79 \%)$.

4-tert-Butyl 2-isopropyl $\quad(2 S, 4 S, 5 R)$-5-(4-methoxyphenyl)-2,4pyrrolidinodicarboxylate (5eb): Sticky oil $(290 \mathrm{mg}, 80 \%) ;[\alpha]_{\mathrm{D}}^{20}=+26.6^{\circ}$ $\left(c=0.9, \mathrm{CHCl}_{3}, 98 \%\right.$ ee by HPLC); $R_{\mathrm{f}}: 0.37$ ( $n$-hexane/ethyl acetate: $\left.3 / 2\right)$; IR (liq.) v. $1730,1727,2978 \mathrm{~cm}^{-1} ;{ }^{1} \mathrm{H}$ NMR $\delta_{\mathrm{H}}: 1.07$ [s, 9H, $\left.\mathrm{CO}_{2} \mathrm{C}\left(\mathrm{CH}_{3}\right)_{3}\right]$, 1.30 [d, $J=6.3 \mathrm{~Hz}, 6 \mathrm{H}, \mathrm{CO}_{2} \mathrm{CH}\left(\mathrm{CH}_{3}\right)_{2}$ ] $, 2.25\left(\mathrm{~m}, 1 \mathrm{H}, \mathrm{CH}_{2}\right), 2.41(\mathrm{~m}, 1 \mathrm{H}$, $\left.\mathrm{CH}_{2}\right), 3.24(\mathrm{dd}, J=14.7,7.7 \mathrm{~Hz}, 1 \mathrm{H}, \mathrm{CHCO} 2 t \mathrm{Bu}), 3.79\left(\mathrm{~s}, 3 \mathrm{H}, \mathrm{OCH}_{3}\right), 3.86$ $(\mathrm{m}, 1 \mathrm{H}, \mathrm{CHCO} 2 \mathrm{Pr}), 4.43(\mathrm{~d}, J=7.9 \mathrm{~Hz}, 1 \mathrm{H}, \mathrm{CHAr}), 5.14$ [sept, $J=6.3$, $\left.1 \mathrm{H}, \mathrm{CO}_{2} \mathrm{CH}\left(\mathrm{CH}_{3}\right)_{2}\right], 6.85(\mathrm{~d}, J=8.8 \mathrm{~Hz}, 2 \mathrm{H}, \mathrm{Ar} H), 7.28(\mathrm{~d}, J=8.7 \mathrm{~Hz}, 2 \mathrm{H}$, $\mathrm{Ar} H) ;{ }^{13} \mathrm{C}$ NMR $\delta_{\mathrm{C}}: 21.8\left[\mathrm{CO}_{2} \mathrm{CH}\left(\mathrm{CH}_{3}\right)_{2}\right], 27.5\left[\mathrm{CO}_{2} \mathrm{C}\left(\mathrm{CH}_{3}\right)_{3}\right], 34.2\left(\mathrm{CH}_{2}\right)$, $50.4\left(\mathrm{CHCO}_{2} t \mathrm{Bu}\right), 55.3\left(\mathrm{OCH}_{3}\right), 60.1\left(\mathrm{CHCO}_{2} \mathrm{Pr}\right), 65.0\left[\mathrm{CO}_{2} \mathrm{CH}\left(\mathrm{CH}_{3}\right)_{2}\right]$, $68.7(\mathrm{PhCH}), 80.5 \quad\left[\mathrm{CO}_{2} \mathrm{C}\left(\mathrm{CH}_{3}\right)_{3}\right], 113.5,128.3(\mathrm{ArCH}), 131.8,158.8$ (ArC), 171.9, $172.9\left(\mathrm{CO}_{2} i \mathrm{Pr}, \mathrm{CO}_{2} t \mathrm{Bu}\right)$; MS (EI) $\mathrm{m} / z(\%): 363\left(\mathrm{M}^{+}, 2.9 \%\right)$, 306 (41), 290 (23), 276 (43), 235 (61), 221 (10), 220 (70), 202 (32), 193 (14), 176 (27), 175 (39), 174 (30), 159 (19), 148 (18), 147 (100), 135 (11), 132 (16), 57 (14), 56 (41), 55 (18); HRMS calcd. for $\mathrm{C}_{20} \mathrm{H}_{29} \mathrm{NO}_{5}: 363.2046$, found: 363.2029; HPLC (column AS, $1 \mathrm{~mL} / \mathrm{min}, n$-hexane $/ i$-PrOH: $95: 5, \lambda$ $220 \mathrm{~nm}), \mathrm{t}_{\mathrm{Rmaj}}=9.5 \mathrm{~min}, \mathrm{t}_{\mathrm{Rmin}}=24.9 \mathrm{~min}$.

4-tert-Butyl 2-methyl (2S,4S,5R)-5-(4-chlorophenyl)-2,4pyrrolidinodicarboxylate (5fa). ${ }^{[11 \mathrm{j}]}(269 \mathrm{mg}, 76 \%)$.

4-tert-Butyl 2-isopropyl (2S,4S,5R)-5-(4-chlorophenyl)-2,4pyrrolidinodicarboxylate (5fb): Colourless prisms (283 mg, 77\%); mp: $88-$ $90{ }^{\circ} \mathrm{C}\left(\mathrm{CH}_{2} \mathrm{Cl}_{2} /\right.$ hexane $) ;[\alpha]_{\mathrm{D}}{ }^{20}=+23.6^{\circ} \quad\left(c=0.8, \mathrm{CHCl}_{3}, 94 \%\right.$ ee by HPLC); $R_{\mathrm{f}}: 0.46$ ( $n$-hexane/ethyl acetate: $3 / 2$ ); IR (liq.) v. 1737, 1709, 2978 $\mathrm{cm}^{-1}$; ${ }^{1} \mathrm{H}$ NMR $\delta_{\mathrm{H}}: 1.06\left[\mathrm{~s}, 9 \mathrm{H}, \mathrm{CO}_{2} \mathrm{C}\left(\mathrm{CH}_{3}\right)_{3}\right], 1.29[\mathrm{~d}, J=6.3 \mathrm{~Hz}, 3 \mathrm{H}$, $\left.\mathrm{CO}_{2} \mathrm{CH}\left(\mathrm{CH}_{3}\right)_{2}\right], 1.30\left[\mathrm{~d}, \mathrm{~J}=6.3 \mathrm{~Hz}, 3 \mathrm{H}, \mathrm{CO}_{2} \mathrm{CH}\left(\mathrm{CH}_{3}\right)_{2}\right], 2.26(\mathrm{~m}, 1 \mathrm{H}$, $\left.\mathrm{CH}_{2}\right), 2.44\left(\mathrm{~m}, 1 \mathrm{H}, \mathrm{CH}_{2}\right), 3.26\left(\mathrm{dd}, J=14.7,7.8 \mathrm{~Hz}, 1 \mathrm{H}, \mathrm{CHCO}_{2} t \mathrm{Bu}\right), 3.89$ $\left(\mathrm{dd}, J=8.4,8.4 \mathrm{~Hz}, 1 \mathrm{H}, \mathrm{CHCO}_{2} i \mathrm{Pr}\right), 4.43(\mathrm{~d}, J=7.8 \mathrm{~Hz}, 1 \mathrm{H}, \mathrm{CHPh}), 5.15$ [sept, $\left.J=6.2,1 \mathrm{H}, \mathrm{CO}_{2} \mathrm{CH}\left(\mathrm{CH}_{3}\right)_{2}\right], 7.25-7.31(\mathrm{~m}, 4 \mathrm{H}, \mathrm{Ar} H) ;{ }^{13} \mathrm{C} \mathrm{NMR} \delta_{\mathrm{C}}$ : $21.8\left[\mathrm{CO}_{2} \mathrm{CH}\left(\mathrm{CH}_{3}\right)_{2}\right], 27.5\left[\mathrm{CO}_{2} \mathrm{C}\left(\mathrm{CH}_{3}\right)_{3}\right], 33.9\left(\mathrm{CH}_{2}\right), 50.1\left(\mathrm{CHCO}_{2} t \mathrm{Bu}\right)$, $60.0\left(\mathrm{CHCO}_{2} i \mathrm{Pr}\right), 64.8\left[\mathrm{CO}_{2} \mathrm{CH}\left(\mathrm{CH}_{3}\right)_{2}\right], 68.8(\mathrm{ArCH}), 80.8\left[\mathrm{CO}_{2} \mathrm{C}\left(\mathrm{CH}_{3}\right)_{3}\right]$, 128.2, 128.6, 133.1, 138.3 (ArC), 171.5, $172.9\left(\mathrm{CO}_{2} i \mathrm{Pr}, \mathrm{CO}_{2} t \mathrm{Bu}\right) ; \mathrm{MS}(\mathrm{EI})$ $m / z(\%): 367\left(\mathrm{M}^{+}, 0.66 \%\right), 282$ (14), 280 (40), 239 (10), 226 (33), 225 (13), 224 (100), 206 (15), 197 (12), 180 (12), 179 (13), 178 (18), 151 (19), 57 (11); HRMS calcd. for $\mathrm{C}_{19} \mathrm{H}_{26} \mathrm{ClNO}_{4}$ : 367.1550, found: 367.1547 ; HPLC (column AS, $1 \mathrm{~mL} / \mathrm{min}, n$-hexane $/ i-\mathrm{PrOH}: 95: 5, \lambda 220 \mathrm{~nm}$ ), $\mathrm{t}_{\mathrm{Rmaj}}=6.7 \mathrm{~min}$, $\mathrm{t}_{\mathrm{Rmin}}=16.5 \mathrm{~min}$

4-tert-Butyl 2-methyl (2S,4S,5R)-5-(2-naphthyl)-2,4pyrrolidinodicarboxylate (5ga): ${ }^{[11 \mathrm{j}]}(299 \mathrm{mg}, 78 \%)$.

Methyl

$(1 S, 3 R, 3 \mathrm{a} S, 6 \mathrm{a} R)-5$-methyl-3-phenyl-4,6dioxooctahydropyrrolo[3,4-c]pyrrole-1-carboxylate (9aa): ${ }^{[11 \mathrm{~b}]}(230 \mathrm{mg}$, $80 \%)$.

Methyl (1S,3R3aS,6aR)-5-ethyl-3-phenyl-4,6-dioxooctahydropyrrolo[3,4c]pyrrole-1-carboxylate (10aa) ${ }^{[11 \mathrm{~b}]}$ : $(236 \mathrm{mg}, 78 \%)$.

3,4-Diisopropyl 2-methyl (2S,3S,4S,5R)-5-phenyl-2,3,4pyrrolidinotricarboxylate (11aa): Sticky oil (305 mg, 81\%); $[\alpha]_{\mathrm{D}}{ }^{20}=32.1^{\circ}$ ( $c=0.5, \mathrm{CHCl}_{3}, 82 \%$ ee by HPLC); $R_{\mathrm{f}}: 0.37$ ( $n$-hexane/ethyl acetate: $3 / 2$ ); IR (liq.) v. $1741,1731,2982 \mathrm{~cm}^{-1} ;{ }^{1} \mathrm{H} \mathrm{NMR} \delta_{\mathrm{H}}: 0.65[\mathrm{~d}, J=6.2 \mathrm{~Hz}, 3 \mathrm{H}$, $\left.\mathrm{CH}\left(\mathrm{CH}_{3}\right)_{2}\right], 0.94\left[\mathrm{~d}, J=6.2 \mathrm{~Hz}, 3 \mathrm{H}, \mathrm{CH}\left(\mathrm{CH}_{3}\right)_{2}\right], 1.27[\mathrm{~d}, J=6.2 \mathrm{~Hz}, 3 \mathrm{H}$, $\left.\mathrm{CH}\left(\mathrm{CH}_{3}\right)_{2}\right], 1.28\left[\mathrm{~d}, J=6.2 \mathrm{~Hz}, 3 \mathrm{H}, \mathrm{CH}\left(\mathrm{CH}_{3}\right)_{2}\right], 2.86($ broad s, $1 \mathrm{H}, \mathrm{NH})$, $3.55\left(\mathrm{~m}, 2 \mathrm{H}, 2 \times \mathrm{CHCO}_{2} i \mathrm{Pr}\right), 3.83\left(\mathrm{~s}, 3 \mathrm{H}, \mathrm{CO}_{2} \mathrm{CH}_{3}\right), 4.14(\mathrm{~d}, J=7.3 \mathrm{~Hz}, 1 \mathrm{H}$, $\left.\mathrm{CHCO}_{2} \mathrm{Me}\right), 4.56$ [sept, $J=6.2 \mathrm{~Hz}, 1 \mathrm{H}, \mathrm{CH}\left(\mathrm{CH}_{3}\right)_{2}$ ], $4.65(\mathrm{~d}, J=7.3 \mathrm{~Hz}$, $1 \mathrm{H}, \mathrm{CHPh}), 5.08$ [sept, $\left.J=6.2 \mathrm{~Hz}, 1 \mathrm{H}, \mathrm{CH}\left(\mathrm{CH}_{3}\right)_{2}\right], 7.22-7.34(\mathrm{~m}, 5 \mathrm{H}$, $\mathrm{Ar} H) ;{ }^{13} \mathrm{C}$ NMR $\delta_{\mathrm{C}}: 20.8,21.4,21.6\left[\mathrm{CH}\left(\mathrm{CH}_{3}\right)_{2}\right], 51.4,52.4\left(\mathrm{CHCO}_{2} i \mathrm{Pr}\right)$ $53.8\left(\mathrm{CO}_{2} \mathrm{CH}_{3}\right), 63.4\left[\mathrm{CHCO}_{2} \mathrm{Me}\right], 65.2(\mathrm{PhCH}), 68.2,68.8\left[\mathrm{CH}\left(\mathrm{CH}_{3}\right)_{2}\right]$, 127.0, 127.7, 128.2, $138.4(\mathrm{ArC}), 170.5,171.5,171.6\left(\mathrm{CO}_{2} \mathrm{Me}, \mathrm{CO}_{2} i \mathrm{Pr}\right)$; MS (EI) $m / z(\%): 377\left(\mathrm{M}^{+}, 14 \%\right), 318$ (33), 317 (23), $316(23), 290$ (20), 276 (17), 274 (12), 258 (38), 248 (15), 230 (43), 228 (17), 216 (10), 205 (25), 202 (50), 188 (47), 187 (23), 177 (67), 170 (34), 149 (12), 146 (29), 145 (46), 144 (100), 143 (29), 119 (22), 118 (19), 117 (96), $116(14), 115$ (28), 106 (11), 104 (10), 91 (12), 90 (10); HRMS calcd. for $\mathrm{C}_{20} \mathrm{H}_{27} \mathrm{NO}_{6}$ : 377.1838, found: 377.1843 ; HPLC (column OD-H, $1 \mathrm{~mL} / \mathrm{min}, n$-hexane $i$ PrOH: 80:20, $\lambda 220 \mathrm{~nm}), \mathrm{t}_{\mathrm{Rmaj}}=6.6 \mathrm{~min}, \mathrm{t}_{\mathrm{Rmin}}=13.5 \mathrm{~min}$.

3,4-Diisobutyl 2-methyl

$(2 S, 3 S, 4 S, 5 R)-5$-phenyl-2,3,4 pyrrolidinotricarboxylate (12aa): Sticky oil (320 mg, 79\%); $[\alpha]_{\mathrm{D}}{ }^{20}=47.1^{\circ}$ $\left(c=0.5, \mathrm{CHCl}_{3}, 82 \%\right.$ ee by HPLC); $R_{\mathrm{f}}: 0.56$ ( $n$-hexane/ethyl acetate: $\left.1 / 5\right)$; IR (liq.) v. $17371730,2958 \mathrm{~cm}^{-1}$; ${ }^{1} \mathrm{H}$ NMR $\delta_{\mathrm{H}}: 0.66[\mathrm{~d}, J=6.7 \mathrm{~Hz}, 3 \mathrm{H}$, $\left.\mathrm{CH}\left(\mathrm{CH}_{3}\right)_{2}\right], 0.68\left[\mathrm{~d}, J=6.6 \mathrm{~Hz}, 3 \mathrm{H}, \mathrm{CH}\left(\mathrm{CH}_{3}\right)_{2}\right], 0.95[\mathrm{~d}, J=6.7 \mathrm{~Hz}, 6 \mathrm{H}$, $\left.\mathrm{CH}\left(\mathrm{CH}_{3}\right)_{2}\right], 1.51\left[\mathrm{~d}, J=6.7 \mathrm{~Hz}, 1 \mathrm{H}, \mathrm{CH}\left(\mathrm{CH}_{3}\right)_{2}\right], 1.63($ broad s, $1 \mathrm{H}, \mathrm{NH})$, $1.97\left[\mathrm{~d}, J=6.7 \mathrm{~Hz}, 1 \mathrm{H}, \mathrm{CH}\left(\mathrm{CH}_{3}\right)_{2}\right], 3.25[\mathrm{dd}, J=10.5,6.6 \mathrm{~Hz}, 1 \mathrm{H}$,
$\mathrm{CH}_{2} \mathrm{CH}\left(\mathrm{CH}_{3}\right)_{2}$ ], 3.50 [dd, $\left.J=10.6,6.6 \mathrm{~Hz}, 1 \mathrm{H}, \mathrm{CH}_{2} \mathrm{CH}\left(\mathrm{CH}_{3}\right)_{2}\right], 3.63$ (m, $\left.2 \mathrm{H}, 2 \times \mathrm{CHCO}_{2} i \mathrm{Bu}\right), 3.83\left(\mathrm{~s}, 3 \mathrm{H}, \mathrm{CO}_{2} \mathrm{CH}_{3}\right), 3.96\left[\mathrm{~m}, 2 \mathrm{H}, \mathrm{CH}_{2} \mathrm{CH}\left(\mathrm{CH}_{3}\right)_{2}\right]$, 4.19 (d, $\left.J=7.3 \mathrm{~Hz}, 1 \mathrm{H}, \mathrm{CHCO}_{2} \mathrm{Me}\right), 4.66$ (d, $\left.J=7.5 \mathrm{~Hz}, 1 \mathrm{H}, \mathrm{CHPh}\right), 7.25-$ $7.32(\mathrm{~m}, 5 \mathrm{H}, \mathrm{Ar} H) ;{ }^{13} \mathrm{C} \mathrm{NMR} \delta_{\mathrm{C}}: 18.8,18.9,19.0\left[\mathrm{CH}\left(\mathrm{CH}_{3}\right)_{2}\right], 27.2,27.7$ $\left[\mathrm{CH}\left(\mathrm{CH}_{3}\right)_{2}\right], 51.3\left(\mathrm{CHCO}_{2} i \mathrm{Bu}\right), 52.5\left(\mathrm{CO}_{2} \mathrm{CH}_{3}\right), 54.0\left(\mathrm{CHCO}_{2} i \mathrm{Bu}\right), 63.4$ $\left[\mathrm{CHCO}_{2} \mathrm{Me}\right], 65.5(\mathrm{PhCH}), 71.1,71.5\left(2 \mathrm{xCH}_{2}\right), 126.9,127.8,128.3,138.1$ (ArC), 171.4, 172.1, $172.2\left(\mathrm{CO}_{2} \mathrm{Me}, 2 \mathrm{xCO}_{2} i \mathrm{Bu}\right) ; \mathrm{MS}(\mathrm{EI}) \quad m / z(\%): 405$ $\left(\mathrm{M}^{+}, 11 \%\right), 346(11), 345(22), 332$ (20), 304 (20), 272 (36), 245 (11), 244 (54), 219 (11), 202 (38), 188 (38), 178 (11), 177 (90), 170 (26), 164 (46), 155 (12),149 (14), 146 (54), 145 (46), 144 (82), 143 (24), 119 (12), 118 (19), 117 (100), 116 (13), 115 (21), 106 (11), 105 (11), 90 (11), 57 (46), 56 (21), 55 (12); HRMS calcd. for $\mathrm{C}_{22} \mathrm{H}_{31} \mathrm{NO}_{6}$ : 405.2151, found: 405.2151; HPLC (column OD-H, $1 \mathrm{~mL} / \mathrm{min}, n$-hexane $/ i$-PrOH: 80:20, $\lambda 220 \mathrm{~nm}$ ), $\mathrm{t}_{\mathrm{Rmaj}}$ $=8.5 \mathrm{~min}, \mathrm{t}_{\mathrm{R} \min }=16.7 \mathrm{~min}$.

2-Methyl (2S,3R,4S,5R)-4-benzoyl-3,5-diphenyl-2-pyrrolidinocarboxylate (13aa): Colourless needles $(262 \mathrm{mg}, 80 \%)$; mp: $152{ }^{\circ} \mathrm{C}$ (hexane/ethyl acetate); $[\alpha]_{\mathrm{D}}{ }^{20}=-20^{\circ}\left(c=1, \mathrm{CH}_{2} \mathrm{Cl}_{2}, 99 \%\right.$ ee by HPLC); IR $(\mathrm{KBr}) v$ : $1673,1741,3435 \mathrm{~cm}^{-1} ;{ }^{1} \mathrm{H}$ NMR $\delta_{\mathrm{H}}: 2.65(\mathrm{~s}, 1 \mathrm{H}, \mathrm{NH}), 3.74(\mathrm{~s}, 3 \mathrm{H}$, $\left.\mathrm{CO}_{2} \mathrm{Me}\right), 4.21-4.09\left(\mathrm{~m}, 2 \mathrm{H}, \mathrm{CHCOPh}\right.$ and $\left.\mathrm{CHCO}_{2} \mathrm{Me}\right), 4.52(\mathrm{t}, J=7.5 \mathrm{~Hz}$, $1 \mathrm{H}, \mathrm{CHPh}), 5.00$ (d, $J=8.6 \mathrm{~Hz}, 1 \mathrm{H}, \mathrm{CHAr}), 7.13-7.04$ (m, 5H, ArH), 7.26$7.21(\mathrm{~m}, 3 \mathrm{H}, \mathrm{Ar} H)$, 7.41-7.31 (m, 5H, ArH), 7.54-7.51 (m, 2H, ArH) ppm. ${ }^{13} \mathrm{C}$ RMN $\delta_{\mathrm{C}}: 52.30\left(\mathrm{CH}_{3} \mathrm{CO}_{2}\right), 52.65(\mathrm{CHPh}), 60.56(\mathrm{CHCOPh}), 66.62$ $\left(\mathrm{CHCO}_{2} \mathrm{Me}\right), 67.63(\mathrm{PhCHNH}), 127.11,1.27 .34,127.72,128.01,128.10$, $128.18,128.76,132.75,137.35,138.90,140.68(\mathrm{ArC}), 173.30$ and 198.61 (2xCO) ppm; HRMS (EI): $\left(\mathrm{M}-\mathrm{C}_{2} \mathrm{H}_{3} \mathrm{O}_{2}\right)^{+}$found $327.1622 \mathrm{C}_{23} \mathrm{H}_{21} \mathrm{NO}$ requires 327.1623; HPLC (column OD-H 90-10-1, $\lambda=220 \mathrm{~nm}$ ) $t_{\text {Rmaj }}=18.4$ $\min , \mathrm{t}_{\mathrm{R} \min }=33.2 \mathrm{~min}$. MS (EI) $m / z 326\left(\mathrm{M}^{+}, 12 \%\right)$.

2-Methyl (2S,3R,4S,5R)-4-benzoyl-5-(2-methylphenyl)-3-phenyl-2pyrrolidinocarboxylate (14ba): Colourless prisms $(141,70 \%), \mathrm{mp}: 128^{\circ} \mathrm{C}$; $[\alpha]_{\mathrm{D}}{ }^{20}=-9\left(\mathrm{c}=1.15, \mathrm{CH}_{2} \mathrm{Cl}_{2}, 99 \%\right.$ ee by HPLC $) ; \mathrm{IR}(\mathrm{KBr}) \mathrm{v}: 1672,1746$, $3373 \mathrm{~cm}^{-1}$; $1 \mathrm{H} \mathrm{NMR} \delta_{\mathrm{H}}: 2.14\left(\mathrm{~s}, 3 \mathrm{H}, \mathrm{CH}_{3} \mathrm{Ph}\right), 3.77\left(\mathrm{~s}, 3 \mathrm{H}, \mathrm{CO}_{2} \mathrm{CH}_{3}\right), 4.12-$ $410\left(\mathrm{~m}, 2 \mathrm{H}, \mathrm{CHCOPh}\right.$ and $\left.\mathrm{CHCO}_{2} \mathrm{Me}\right), 4.52-4.43(\mathrm{~m}, 1 \mathrm{H}, \mathrm{CHPh}), 5.11(\mathrm{~d}$, $J=8.3 \mathrm{~Hz}, 1 \mathrm{H}, C H \mathrm{Ar}), 6.75(\mathrm{~d}, J=7.7 \mathrm{~Hz}, 1 \mathrm{H}), 6.92(\mathrm{t}, J=6.4 \mathrm{~Hz}, 1 \mathrm{H}$, $\mathrm{Ar} H), 7.17-7.05(\mathrm{~m}, 3 \mathrm{H}, \mathrm{Ar} H), 7.41-7.24(\mathrm{~m}, 9 \mathrm{H}, \mathrm{Ar} H) \mathrm{ppm} .{ }^{13} \mathrm{C} \mathrm{RMN} \delta \mathrm{c}:$ $19.9\left(\mathrm{CH}_{3} \mathrm{Ph}\right), 52.7\left(\mathrm{CH}_{3} \mathrm{CO}_{2}\right), 54.4(\mathrm{CHPh}), 59.7\left(\mathrm{CHCO}_{2} \mathrm{Me}\right), 63.3$ (CHCOPh), 68.5 (CHAr), 126.5, 126.6, 127.5, 127.7, 127.9, 127.9, 128.3, $129.3,130.3,132.8,135.2,136.2,138.1,142.1(\mathrm{ArC}), 173.22\left(\mathrm{CO}_{2} \mathrm{Me}\right)$, $200.93(\mathrm{COPh}) \mathrm{ppm}$; MS (EI) $m / z 340 \quad\left(\mathrm{M}^{+}, 15 \%\right)$; HRMS (EI): (M$\left.\mathrm{C}_{2} \mathrm{H}_{3} \mathrm{O}_{2}\right)^{+}$found $340.1685 \mathrm{C}_{24} \mathrm{H}_{22} \mathrm{NO}$ requires 341.1780 ; HPLC (column Chiralpak OD-H 90-10-1, $\lambda=220 \mathrm{~nm}) \mathrm{t}_{\mathrm{Rmaj}}=19.7, \mathrm{t}_{\mathrm{Rmin}}=24.8$.

2-Methyl $\quad(2 S, 3 R, 4 S, 5 R)-4-b e n z o y l-5-(4-m e t h y l p h e n y l)-3-p h e n y l-2-$ pyrrolidinocarboxylate (14da): Colourles prisms (256 mg, 75\%), mp: 154 ${ }^{\circ} \mathrm{C},[\alpha]_{\mathrm{D}}{ }^{20}=-25\left(c=1.06, \mathrm{CH}_{2} \mathrm{Cl}_{2}, 90 \%\right.$ ee by HPLC); IR (KBr) v: 1675 , $1741,3374 \mathrm{~cm}^{-1} ;{ }^{1} \mathrm{H}$ NMR $\delta_{\mathrm{H}}: 2.17\left(\mathrm{~s}, 3 \mathrm{H}, \mathrm{CH}_{3} \mathrm{Ph}\right), 3.73\left(\mathrm{~s}, 3 \mathrm{H}, \mathrm{CO}_{2} \mathrm{Me}\right)$, 4.18-4.07 (m, 2H, $\mathrm{CHCOPh}$ and $\left.\mathrm{CHCO}_{2} \mathrm{Me}\right), 4.50(\mathrm{t}, J=7.8 \mathrm{~Hz}, 1 \mathrm{H}$, $C H \mathrm{Ph}), 4.97$ (d, $J=8.6 \mathrm{~Hz}, 1 \mathrm{H}, C H \mathrm{Ar}), 6.9(\mathrm{~d}, J=8.0 \mathrm{~Hz}, 2 \mathrm{H}, \mathrm{ArH}), 6.99$ $(\mathrm{d}, J=8.1 \mathrm{~Hz}, 2 \mathrm{H}, \mathrm{Ar} H), 7.39-7.42(\mathrm{~m}, 9 \mathrm{H}, \mathrm{Ar} H), 7.55$ (d, $J=6.4 \mathrm{~Hz}, 2 \mathrm{H}$, $\mathrm{ArH}) \mathrm{ppm} ;{ }^{13} \mathrm{C} \mathrm{RMN} \delta \mathrm{c}: 20.9\left(\mathrm{CH}_{3} \mathrm{Ph}\right), 52.2\left(\mathrm{CO}_{2} \mathrm{CH}_{3}\right), 52.6(\mathrm{CHPh}), 60.6$ $\left(\mathrm{CHCO}_{2} \mathrm{Me}\right), 66.4(\mathrm{CHCOPh}), 67.6$ (CHAr), 127.2, 128.0, 128.7, 128.7 , 132.7, 136.0, 137.2, 137.4, $140.7(\mathrm{ArC}), 173.4\left(\mathrm{CO}_{2} \mathrm{Me}\right), 198.6(\mathrm{COPh})$ ppm; MS (EI) m/z $340\left(\mathrm{M}^{+}, 45 \%\right)$; HRMS (EI): $\left(\mathrm{M}-\mathrm{C}_{2} \mathrm{H}_{3} \mathrm{O}_{2}\right)^{+}$found $340.1705 \mathrm{C}_{24} \mathrm{H}_{22} \mathrm{NO}$ requires 341.1780 . HPLC (column Chiralpak ODH 90$10-1 \lambda=220 \mathrm{~nm}) \mathrm{t}_{\mathrm{Rmaj}}=19.7, \mathrm{t}_{\mathrm{Rmin}}=24.8$.

Methyl

(1S,3R,3aS,6aR)-octahydro-3-(naphthalen-2-yl)-4oxocyclopenta[c]pyrrole-1-carboxylate (15ga): $:^{[12 b]}(222 \mathrm{mg}, 72 \%)$

4-tert-Butyl 2-methyl (2S,4S,5R)-2-methyl-5-phenyl-2,4pyrrolidinodicarboxylate (16aa) ${ }^{[11 \mathrm{j}]}(238 \mathrm{mg}, 78 \%)$

4-tert-Butyl 2-methyl (2S,4S,5R)-2-benzyl-5-phenyl-2,4pyrrolidinodicarboxylate (17aa): ${ }^{[11 \mathrm{j}]}(293,77 \%)$.

4-tert-Butyl 2-methyl $\quad(2 S, 4 S, 5 R)$-2-methyl-5-(2-thienyl)-2,4pyrrolidinodicarboxylate (18ha): Sticky oil $(257 \mathrm{mg}, 79 \%) ;[\alpha]_{\mathrm{D}}{ }^{20}=+46.3^{\circ}$ ( $c=1, \mathrm{CHCl}_{3}, 92 \%$ ee by HPLC); $R_{\mathrm{f}}: 0.30$ ( $n$-hexane/ethyl acetate: $3 / 2$ ); IR (liq.) v. $1728,1725,2977 \mathrm{~cm}^{-1} ;{ }^{1} \mathrm{H} \mathrm{NMR} \delta_{\mathrm{H}}: 1.15\left[\mathrm{~s}, 9 \mathrm{H}, \mathrm{CO}_{2} \mathrm{C}\left(\mathrm{CH}_{3}\right)_{3}\right]$, $1.46\left(\mathrm{~s}, 1 \mathrm{H}, \mathrm{CCH}_{3}\right), 2.07\left(\mathrm{dd}, J=13.7,7.7 \mathrm{~Hz}, 1 \mathrm{H}, \mathrm{CH}_{2}\right), 2.70(\mathrm{dd}, J=$ 13.7, $\left.7.7 \mathrm{~Hz}, 1 \mathrm{H}, \mathrm{CH}_{2}\right), 3.35\left(\mathrm{dd}, J=15.2,7.7 \mathrm{~Hz}, 1 \mathrm{H}, \mathrm{CHCO}_{2} t \mathrm{Bu}\right), 3.79$ $\left(\mathrm{s}, 3 \mathrm{H}, \mathrm{CO}_{2} \mathrm{CH}_{3}\right), 4.81(\mathrm{~d}, J=7.5 \mathrm{~Hz}, 1 \mathrm{H}, \mathrm{CHAr}), 6.91-6.95(\mathrm{~m}, 2 \mathrm{H}, \mathrm{ArH})$, $7.17(\mathrm{dd}, J=4.9,0.9 \mathrm{~Hz}, 1 \mathrm{H}, \mathrm{ArH}) ;{ }^{13} \mathrm{C} \mathrm{NMR} \delta_{\mathrm{C}}: 27.6\left(\mathrm{CCH}_{3}\right), 27.8$ $\left(\mathrm{CCH}_{3}\right), 39.4\left(\mathrm{CH}_{2}\right), 50.6\left(\mathrm{CHCO}_{2} t \mathrm{Bu}\right), 52.5\left[\mathrm{CO}_{2} \mathrm{C}\left(\mathrm{CH}_{3}\right)_{3}\right], 60.3(\mathrm{ArCH})$, $80.8\left[\mathrm{CO}_{2} \mathrm{C}\left(\mathrm{CH}_{3}\right)_{3}\right], 124.1,124.8,126.5,143.5(\mathrm{ArC}), 171.0,176.3$ $\left(\mathrm{CO}_{2} \mathrm{Me}, \mathrm{CO}_{2} t \mathrm{Bu}\right)$; MS (EI) $m / z(\%): 325\left(\mathrm{M}^{+}, 3.4 \%\right), 268$ (22), 267 (10), 266 (65), 252 (26), 211 (12), 210 (100), 197 (56), 166 (15), 165 (15), 164 (18), 137 (67), 96 (11), 57 (18), 53 (10); HRMS calcd. for $\mathrm{C}_{16} \mathrm{H}_{23} \mathrm{NO}_{4} \mathrm{~S}$ : 
325.1348, found: 325.1347 ; HPLC (column OD-H, $1 \mathrm{~mL} / \mathrm{min}, n$-hexane $/ i$ PrOH: 99:1, $\lambda 220 \mathrm{~nm}), \mathrm{t}_{\mathrm{Rmaj}}=13.4 \mathrm{~min}, \mathrm{t}_{\mathrm{Rmin}}=14.8 \mathrm{~min}$.

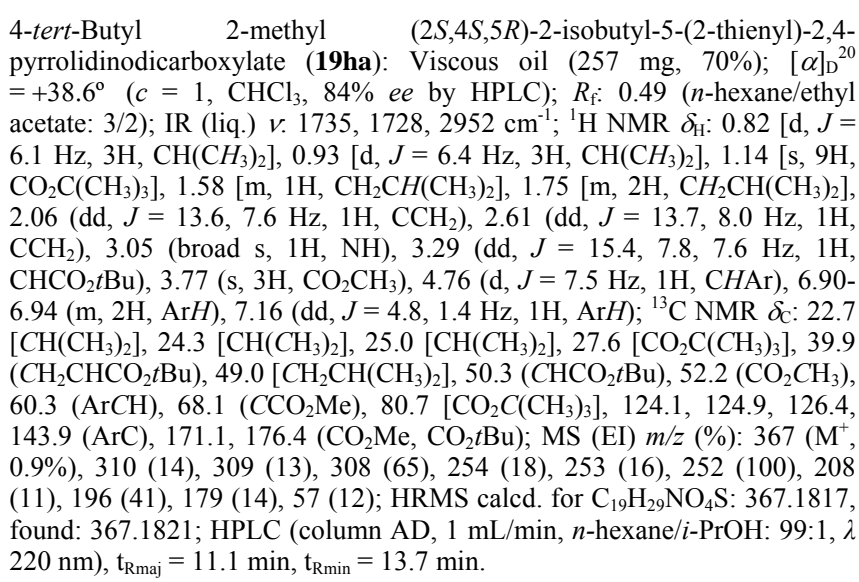

Methyl

$(1 S, 3 R 3 \mathrm{a} S, 6 \mathrm{a} R)-1,5$-dimethyl-3-phenyl-4,6dioxooctahydropyrrolo[3,4-c]pyrrole-1-carboxylate (20aa): $:^{[11 \mathrm{~b}]}(242 \mathrm{mg}$, $80 \%)$. Methyl $(1 S, 3 R 3 \mathrm{a} S, 6 \mathrm{a} R)-1-$ benzyl-5-methyl-4,6-dioxo-3-phenyl-
octahydropyrrolo[3,4-c]pyrrole-1-carboxylate (21aa) $:^{[11 \mathrm{~b}]}(302 \mathrm{mg}, 80 \%)$.

Methyl (2S,3R,4S,5R)-4-benzoyl-2-methyl-3,5-diphenyl-2pyrrolidinocarboxylate (22aa): ${ }^{[12 \mathrm{~b}, 31]}(324 \%, 81 \%)$.

Methyl

(2S,3R,4S,5R)-4-acetyl-2,3-dimethyl-5-(2-naphthyl)-2 pyrrolidinocarboxylate (23ga): Pale yellow oil $(189 \mathrm{mg}, 71 \%) ;[\alpha]_{\mathrm{D}}{ }^{20}=20$ $\left(c=1.02, \mathrm{CH}_{2} \mathrm{Cl}_{2}, 65 \%\right.$ ee by HPLC); IR (NaCl) v: 1689, 1722, 2958, 3312 $\mathrm{cm}^{-1} .{ }^{1} \mathrm{H}$ NMR $\delta_{\mathrm{H}}: 1.19\left(\mathrm{~d}, J=6.2 \mathrm{~Hz}, 3 \mathrm{H}, \mathrm{CH}_{3} \mathrm{CH}\right), 1.38\left(\mathrm{~s}, 3 \mathrm{H}, \mathrm{CH}_{3} \mathrm{CN}\right)$, $1.61\left(\mathrm{~s}, 3 \mathrm{H}, \mathrm{CH}_{3} \mathrm{CO}\right), 2.99-3.04\left(\mathrm{~m}, 1 \mathrm{H}, \mathrm{CHCH}_{3}\right), 3.29(\mathrm{t}, J=10.3 \mathrm{~Hz}, 1 \mathrm{H}$, $\mathrm{CHCO}), 3.82\left(\mathrm{~s}, 3 \mathrm{H}, \mathrm{OCH}_{3}\right), 4.90(\mathrm{~d}, J=9.5 \mathrm{~Hz}, 1 \mathrm{H} \mathrm{CHN}), 7.37-7.34(\mathrm{~m}$, $2 \mathrm{H}, \mathrm{ArH}), 7.48-7.43(\mathrm{~m}, 3 \mathrm{H}, \mathrm{ArH}) \mathrm{ppm} .{ }^{13} \mathrm{C}$ NMR $\delta \mathrm{c}: 19.77\left(\mathrm{CH}_{3} \mathrm{CH}\right)$ $24.99\left(\mathrm{CH}_{3} \mathrm{CCO}\right), 30.60\left(\mathrm{CHCH}_{3}\right), 42.58(\mathrm{CHCO}), 52.17\left(\mathrm{CH}_{3} \mathrm{O}\right), 62.23$ (CHCO), 64.47 (CHN), 125.05, 125.88, 126.38, 127.31127 .60128 .18 ,
132.72, $137.67(\mathrm{ArC}), 175.57\left(\mathrm{CO}_{2}\right), 206.59\left(\mathrm{COCH}_{3}\right) \mathrm{ppm} ; \mathrm{MS}(\mathrm{EI}) \mathrm{m} / z$ $266\left(\mathrm{M}^{+}\right)$; HRMS (EI): $\left(\mathrm{M}-\mathrm{C}_{2} \mathrm{H}_{3} \mathrm{O}_{2}\right)^{+}$found $266.1552, \mathrm{C}_{18} \mathrm{H}_{20} \mathrm{NO}$ requires 266.1555; HPLC (column Chiralpak ODH 90-10-1, $\lambda=220 \mathrm{~nm}$ ) $\mathrm{t}_{\mathrm{Rmaj}}=10.5$ $\min , \mathrm{t}_{\mathrm{Rmin}}=12.2 \mathrm{~min}$.

Synthesis of antiviral compound (2S,4S,5R)-26. Compound $(2 S, 4 S, 5 R)-$ 8ha $(1.2 \mathrm{mmol}, 441 \mathrm{mg})$ was dissolved in dichlorometane $(25 \mathrm{~mL})$ and triethylamine $(1.2 \mathrm{mmol}, 166 \mu \mathrm{L})$ and 4-(trifluoromethyl)benzoyl chloride $(1.2 \mathrm{mmol}, 182 \mu \mathrm{L})$ were slowly added at $0{ }^{\circ} \mathrm{C}$. The resulting mixture was refluxed overnight and the solvent was removed under vacuo (15 Torr) Crude compound $(2 S, 4 S, 5 R)-25$, was allowed to react with trifluoroacetic acid/dichloromethane mixture $(9.6 \mathrm{~mL} / 18 \mathrm{~mL})$. The resulting mixture was stirred at room temperature overnight and the solvent evaporated under vacuo. The residue was dissolved in a $1 \mathrm{M}$ solution of $\mathrm{KOH}$ in a $4 / 1$ $\mathrm{MeOH} / \mathrm{H}_{2} \mathrm{O}(50 \mathrm{~mL})$. This reaction was refluxed for $16 \mathrm{~h}$. Methanol was evaporated and aqueous $\mathrm{HCl}(0.5 \mathrm{M}, 20 \mathrm{~mL})$ and ethyl acetate were added $(2 \times 20 \mathrm{~mL})$. The combined organic phases were dried $\left(\mathrm{MgSO}_{4}\right)$ and evaporated, yielding the crude compound $(2 S, 4 S, 5 R)-26$, which was recrystallised from a mixture containing acetone/chloroform.

(2S,4S,5R)-2-Isobutyl-5-(2-thienyl)-1-[4-(trifluoromethyl)benzoyl]-2,4pyrrolidinodicarboxílic acid $[(2 S, 4 S, 5 R)-(+)-26]:^{[5 a]}$ (395 mg, 71\% from 19ha)

Supporting Information (see footnote on the first page of this article).

\section{Acknowledgments}

This work has been supported by the DGES of the Spanish Ministerio de Educación y Ciencia (MEC) (Consolider INGENIO 2010 CSD2007-00006, CTQ2007-62771/BQU, and CTQ2004-00808/BQU), and by the University of Alicante. M. G. Retamosa and M. Martín-Rodríguez thanks the University of Alicante and MEC, respectively, for a predoctoral fellowship. The authors also thank the SGI/IZO-SGIker UPV/EHU for generous allocation of computational resources. 
Table 1. Optimization of the 1,3-DC of iminoesters 4 (1 equiv) and tert-butyl acrylate ( 1 equiv.) in toluene catalyzed by a 5 mol- $\%$ of both chiral ligand and $\mathrm{Ag}^{\mathrm{I}}$ salt using $5 \mathrm{~mol}-\%$ of base.

\begin{tabular}{|c|c|c|c|c|c|c|c|c|c|c|}
\hline Entry & $\mathrm{R}$ & Iminoester & $\operatorname{AgX}$ & Ligand & Base & $T\left[{ }^{\circ} \mathrm{C}\right]$ & $t[\mathrm{~h}]$ & Cycloadduct & Conv. [\%] & $e r^{[a]}$ \\
\hline 1 & $\mathrm{Me}$ & 4aa & $\mathrm{AgClO}_{4}$ & $\left(S_{\mathrm{a}}\right)-\mathbf{1}$ & $\mathrm{Et}_{3} \mathrm{~N}$ & 20 & 8 & 5aа & 98 & $76: 24$ \\
\hline 2 & $\mathrm{Me}$ & 4aa & $\mathrm{AgClO}_{4}$ & $\left(S_{\mathrm{a}}, R\right)-2$ & $\mathrm{Et}_{3} \mathrm{~N}$ & 20 & 8 & 5аa & 98 & $69: 31$ \\
\hline 3 & $\mathrm{Me}$ & 4aa & $\mathrm{AgClO}_{4}$ & $\left(S_{\mathrm{a},}, R, R\right)-\mathbf{3}$ & $\mathrm{Et}_{3} \mathrm{~N}$ & 20 & 8 & 5aa & 98 & $85: 15$ \\
\hline 4 & $\mathrm{Me}$ & 4aa & $\mathrm{AgClO}_{4}^{[\mathrm{b}]}$ & $\left(S_{\mathrm{a}}, R, R\right)-\mathbf{3}$ & $\mathrm{Et}_{3} \mathrm{~N}$ & 20 & 8 & 5aa & 95 & $74: 26$ \\
\hline 5 & $\mathrm{Me}$ & 4aa & $\mathrm{AgOAc}$ & $\left(S_{\mathrm{a}}, R, R\right)-\mathbf{3}$ & $\mathrm{Et}_{3} \mathrm{~N}$ & 20 & 8 & 5aa & 98 & $80: 20$ \\
\hline 6 & $\mathrm{Me}$ & 4aa & $\mathrm{AgOTf}$ & $\left(S_{\mathrm{a}}, R, R\right)-\mathbf{3}$ & $\mathrm{Et}_{3} \mathrm{~N}$ & 20 & 8 & 5aa & 98 & $84: 16$ \\
\hline 7 & $\mathrm{Me}$ & 4aa & $\mathrm{AgF}$ & $\left(S_{\mathrm{a}}, R, R\right)-\mathbf{3}$ & $\mathrm{Et}_{3} \mathrm{~N}$ & 20 & 8 & 5aa & 90 & $76: 24$ \\
\hline 8 & $\mathrm{Me}$ & 4aa & $\mathrm{AgBF}_{4}$ & $\left(S_{\mathrm{a}}, R, R\right)-\mathbf{3}$ & $\mathrm{Et}_{3} \mathrm{~N}$ & 20 & 8 & 5aa & 95 & $60: 40$ \\
\hline 9 & $\mathrm{Me}$ & 4aa & $\mathrm{AgClO}_{4}$ & $\left(S_{\mathrm{a}}, R, R\right)-\mathbf{3}$ & $\mathrm{Et}_{3} \mathrm{~N}$ & 0 & 16 & $5 a a$ & 96 & $87: 17$ \\
\hline 10 & $\mathrm{Me}$ & 4aa & $\mathrm{AgClO}_{4}$ & $\left(S_{\mathrm{a}}, R, R\right)-\mathbf{3}$ & $\mathrm{Et}_{3} \mathrm{~N}$ & -20 & 16 & 5aa & 98 & $90: 10$ \\
\hline 11 & $\mathrm{Me}$ & $4 a$ & $\mathrm{AgClO}_{4}$ & $\left(S_{\mathrm{a}}\right)-\mathbf{1}$ & $\mathrm{Et}_{3} \mathrm{~N}$ & -20 & 17 & 5аa & 97 & $79: 21$ \\
\hline 12 & $\mathrm{Me}$ & 4aa & $\mathrm{AgClO}_{4}$ & $\left(S_{\mathrm{a}}, R, R\right)-\mathbf{3}$ & DIPEA $^{[\mathrm{cc}]}$ & -20 & 16 & 5aа & 97 & 89:11 \\
\hline 13 & $\mathrm{Me}$ & 4aa & $\mathrm{AgClO}_{4}$ & $\left(S_{\mathrm{a}}, R, R\right)-\mathbf{3}$ & DABCO & -20 & 17 & 5аa & 96 & 94:6 \\
\hline 14 & $\mathrm{Me}$ & 4aa & $\mathrm{AgClO}_{4}$ & $\left(R_{a}, S, S\right)-3$ & DABCO & -20 & 17 & ent-5aa & $>98$ & 6:94 \\
\hline 15 & $i \operatorname{Pr}$ & 4ab & $\mathrm{AgClO}_{4}$ & $\left(S_{\mathrm{a}}, R, R\right)-\mathbf{3}$ & $\mathrm{Et}_{3} \mathrm{~N}$ & 0 & 16 & $5 a b$ & $>98$ & 93:7 \\
\hline 16 & $i \operatorname{Pr}$ & 4ab & $\mathrm{AgClO}_{4}$ & $\left(S_{\mathrm{a}}, R, R\right)-\mathbf{3}$ & $\mathrm{Et}_{3} \mathrm{~N}$ & -20 & 16 & $5 a b$ & $>98$ & $>99: 1$ \\
\hline 17 & $i \operatorname{Pr}$ & 4ab & $\mathrm{AgClO}_{4}$ & $\left(S_{\mathrm{a}}, R, R\right)-\mathbf{3}$ & DABCO & -20 & 16 & $5 a b$ & 97 & $>99: 1$ \\
\hline 18 & $i \operatorname{Pr}$ & 4ab & $\mathrm{AgClO}_{4}$ & $\left(S_{\mathrm{a}}\right)-\mathbf{1}$ & $\mathrm{Et}_{3} \mathrm{~N}$ & -20 & 17 & $5 a b$ & 94 & $53: 47$ \\
\hline 19 & $i \operatorname{Pr}$ & 4ab & $\mathrm{AgClO}_{4}$ & $\left(R_{a}, S, S\right)-3$ & $\mathrm{Et}_{3} \mathrm{~N}$ & -20 & 16 & ent-5ab & 97 & $<1: 99$ \\
\hline 20 & $i \operatorname{Pr}$ & 4ab & $\mathrm{AgClO}_{4}$ & $\left(S_{\mathrm{a}}, R, R\right)-\mathbf{3}$ & $\mathrm{Et}_{3} \mathrm{~N}$ & -20 & 16 & ent-5ab & 95 & $28: 72$ \\
\hline 21 & $i \operatorname{Pr}$ & 4ab & $\mathrm{AgClO}_{4}$ & $\left(S_{a}, S, S\right)-3$ & $\mathrm{Et}_{3} \mathrm{~N}$ & -20 & 16 & ent-5ab & 95 & $28: 72$ \\
\hline 22 & $i \operatorname{Pr}$ & $4 a b$ & $\mathrm{AgClO}_{4}^{[[]]}$ & $\left(S_{\mathrm{a}}, R, R\right)-\mathbf{3}$ & $\mathrm{Et}_{3} \mathrm{~N}$ & -20 & 16 & $5 a b$ & 76 & $98: 2$ \\
\hline
\end{tabular}

[a] Determined by chiral HPLC analysis (Daicel, Chiralpak AS) of the crude product. More than 98:2 endo:exo ratio by ${ }^{1} \mathrm{H}$ NMR spectroscopy. [b] Reaction performed with two equivalents of the ligand 3 and 1 equiv. of silver perchlorate. [c] DIPEA = Diisopropylethylamine. [d] DABCO = 1,4Diazabicyclo[2.2.2]octane. [e] 3 Mol-\% amount of the catalyst was employed.

Table 2. 1,3-DC of glycine derived iminoesters 4 and tert-butyl acrylate catalyzed by 5 mol- $\%$ of $\left(S_{\mathrm{a}}, R, R\right)-3: \mathrm{AgClO}_{4}$ complex.

\begin{tabular}{|c|c|c|c|c|c|c|c|c|}
\hline Entry & $\mathrm{Ar}$ & $\mathrm{R}$ & 4 & Base & $T\left[{ }^{\circ} \mathrm{C}\right]$ & $\begin{array}{l}\text { Cycloadduct } \\
\text { No }\end{array}$ & Yield $[\%]^{[a]}$ & $e r_{\text {endo }}^{[b]}$ \\
\hline 1 & $\mathrm{Ph}$ & $\mathrm{Me}$ & 4aa & $\mathrm{Et}_{3} \mathrm{~N}$ & -20 & 5aа & 80 & $90: 10(90: 10)$ \\
\hline 2 & $\mathrm{Ph}$ & $\mathrm{Me}$ & 4aa & DABCO & -20 & 5aa & 80 & 94:6 (94:6) \\
\hline
\end{tabular}




\begin{tabular}{|c|c|c|c|c|c|c|c|c|}
\hline 3 & $\mathrm{Ph}$ & $i \operatorname{Pr}$ & 4ab & $\mathrm{Et}_{3} \mathrm{~N}$ & -20 & $5 a b$ & 83 & $>99: 1(>91: 1)$ \\
\hline 4 & $\mathrm{Ph}$ & $i \operatorname{Pr}$ & 4ab & DABCO & -20 & $5 a b$ & 81 & $>99: 1(>91: 1)$ \\
\hline 5 & 2-Me- $\mathrm{C}_{6} \mathrm{H}_{4}$ & $\mathrm{Me}$ & $4 \mathbf{b a}$ & DABCO & 0 & $5 \mathbf{b a}$ & 78 & $95: 5(95: 5)$ \\
\hline 6 & 2-Me- $\mathrm{C}_{6} \mathrm{H}_{4}$ & $\mathrm{Me}$ & $4 \mathrm{ba}$ & DABCO & -20 & 5 ba & 83 & $99: 1(>99: 1)$ \\
\hline 7 & 2-Cl- $\mathrm{C}_{6} \mathrm{H}_{4}$ & $\mathrm{Me}$ & $4 \mathbf{c a}$ & DABCO & 0 & 5 ca & 79 & $94: 6(95: 5)$ \\
\hline 8 & 2-Cl- $\mathrm{C}_{6} \mathrm{H}_{4}$ & $\mathrm{Me}$ & $4 \mathrm{ca}$ & DABCO & -20 & $5 \mathrm{ca}$ & 80 & $98: 2(>99: 1)$ \\
\hline 9 & 4-Me- $\mathrm{C}_{6} \mathrm{H}_{4}$ & $\mathrm{Me}$ & 4da & $\mathrm{Et}_{3} \mathrm{~N}$ & -20 & $5 d a$ & 78 & $90: 10(90: 10)$ \\
\hline 10 & 4-Me- $\mathrm{C}_{6} \mathrm{H}_{4}$ & $\mathrm{Me}$ & 4da & DABCO & 0 & 5da & 77 & $90: 10(91: 9)$ \\
\hline 11 & 4-Me- $\mathrm{C}_{6} \mathrm{H}_{4}$ & $\mathrm{Me}$ & 4da & DABCO & -20 & $5 d a$ & 77 & $91: 9(92: 8)$ \\
\hline 12 & 4-Me- $\mathrm{C}_{6} \mathrm{H}_{4}$ & $i \operatorname{Pr}$ & $4 d b$ & $\mathrm{Et}_{3} \mathrm{~N}$ & -20 & $5 d b$ & 80 & $95: 5(96: 4)$ \\
\hline 13 & 4-Me- $\mathrm{C}_{6} \mathrm{H}_{4}$ & $i \operatorname{Pr}$ & $4 d b$ & DABCO & -20 & $5 d b$ & 78 & $94: 6(95: 5)$ \\
\hline 14 & $4-\mathrm{MeO}-\mathrm{C}_{6} \mathrm{H}_{4}$ & $\mathrm{Me}$ & 4ea & DABCO & 0 & 5ea & 77 & $94: 6(94: 6)$ \\
\hline 15 & 4-MeO- $\mathrm{C}_{6} \mathrm{H}_{4}$ & $\mathrm{Me}$ & 4ea & DABCO & -20 & 5ea & 79 & $95: 5(96: 4)$ \\
\hline 16 & $4-\mathrm{MeO}-\mathrm{C}_{6} \mathrm{H}_{4}$ & $i \operatorname{Pr}$ & 4eb & $\mathrm{Et}_{3} \mathrm{~N}$ & -20 & $5 \mathrm{eb}$ & 80 & $99: 1(99: 1)$ \\
\hline 17 & 4-MeO- $\mathrm{C}_{6} \mathrm{H}_{4}$ & $i \operatorname{Pr}$ & 4eb & DABCO & -20 & 5 eb & 76 & $94: 6(95: 5)$ \\
\hline 18 & 4-Cl- $\mathrm{C}_{6} \mathrm{H}_{4}$ & $\mathrm{Me}$ & $4 \mathrm{fa}$ & DABCO & 0 & $5 f a$ & 77 & $92: 8(93: 7)$ \\
\hline 19 & 4-Cl- $\mathrm{C}_{6} \mathrm{H}_{4}$ & $\mathrm{Me}$ & $4 \mathrm{fa}$ & DABCO & -20 & $5 f a$ & 76 & $94: 6(95: 5)$ \\
\hline 20 & 4-Cl- $\mathrm{C}_{6} \mathrm{H}_{4}$ & $i \operatorname{Pr}$ & $4 \mathrm{fb}$ & $\mathrm{Et}_{3} \mathrm{~N}$ & -20 & $5 \mathrm{fb}$ & 77 & $95: 5(97: 3)$ \\
\hline 21 & 4-Cl- $\mathrm{C}_{6} \mathrm{H}_{4}$ & $i \operatorname{Pr}$ & $4 \mathrm{fb}$ & DABCO & 0 & $5 \mathrm{fb}$ & 77 & $92: 8(94: 6)$ \\
\hline 22 & 2-Naphthyl & $\mathrm{Me}$ & 4ga & $\mathrm{Et}_{3} \mathrm{~N}$ & -20 & $5 g a$ & 84 & $95: 5(96: 4)$ \\
\hline 23 & 2-Naphthyl & $\mathrm{Me}$ & 4ga & DABCO & 0 & $5 g a$ & 78 & $90: 10(90: 10)$ \\
\hline 24 & 2-Naphthyl & $\mathrm{Me}$ & 4ga & DABCO & -20 & 5ga & 76 & $92: 8(94: 6)$ \\
\hline
\end{tabular}

[a] Yield obtained after flash chromatography of the endo-product. [b] Determined by chiral HPLC analysis (Daicel, Chiralpak AS) of the crude product. More than 98:2 endo:exo ratio by ${ }^{1} \mathrm{H}$ NMR spectroscopy. In brackets the er of the purified product 5.

Table 3. 1,3-DC of glycine methyl iminoesters 4 and $\alpha$-substituted methyl iminoesters $\mathbf{6 - 8}$ with assorted dipolarophiles, catalyzed by 5 mol-\% of $\left(S_{\mathrm{a}}, R, R\right)$ 3: $\mathrm{AgClO}_{4}$ complex.

\begin{tabular}{|c|c|c|c|c|c|c|c|c|c|c|}
\hline Entry & $\mathrm{Ar}$ & $\mathrm{R}$ & Iminoester & Base & Dipolarophile & $T\left[{ }^{\circ} \mathrm{C}\right]$ & Structure & $\begin{array}{l}\text { Cycloadduct } \\
\text { No }\end{array}$ & $\begin{array}{l}\text { Yield } \\
{[\%]^{[\mathrm{a}]}}\end{array}$ & $e r_{\text {endo }}[\mathrm{b}][\mathrm{c}]$ \\
\hline 1 & $\mathrm{Ph}$ & $\mathrm{H}$ & $4 a a$ & DABCO & $\mathrm{NMM}^{[\mathrm{d}]}$ & 20 & & 9aa & 80 & $>99: 1(>99: 1)$ \\
\hline
\end{tabular}




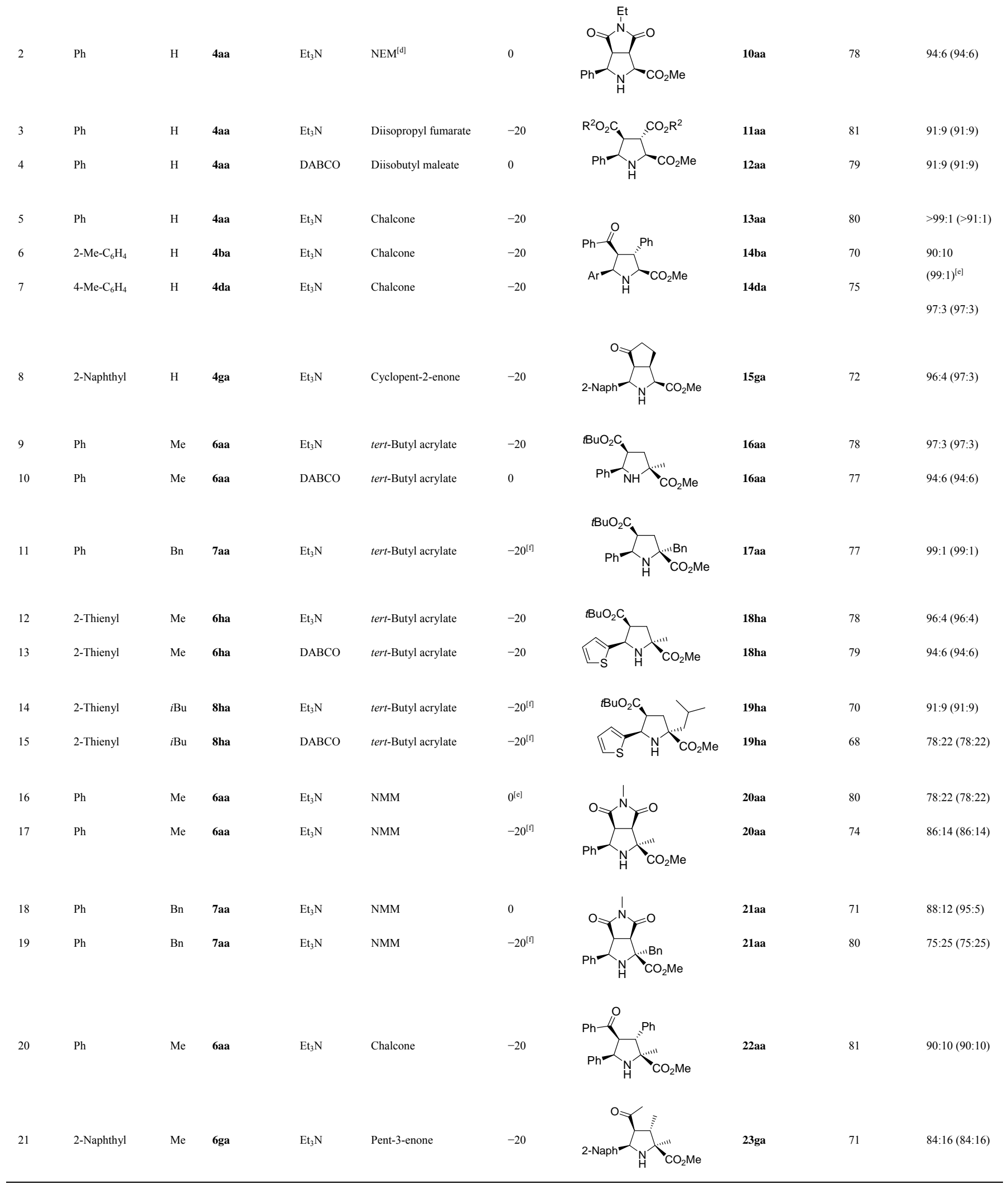

[a] Yield obtained after flash chromatography of the endo-product. [b] Determined by chiral HPLC analysis (see, experimental part) of the crude product. More than 98:2 endo:exo ratio by ${ }^{1} \mathrm{H}$ NMR spectroscopy. [c] In brackets the $e r$ of the purified endo-cycloadduct. [d] The reaction took $6 \mathrm{~h}$. [e] A 70:30 endo:exo mixture was obtained in the crude product. [f] The reaction took $48 \mathrm{~h}$. 


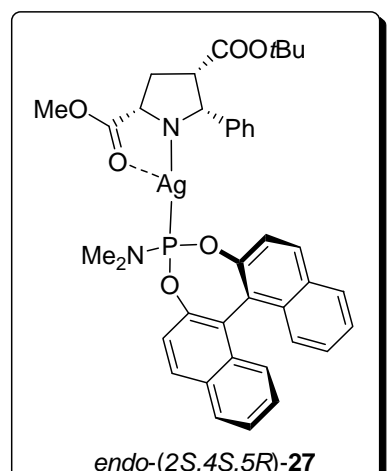<smiles>CCCCOC(=O)C1CC2C(OC)O[Al]([Al]3Oc4ccc5ccccc5c4-c4c(ccc5ccccc45)O3)N2C1c1ccccc1</smiles>

endo- $(2 R, 4 R, 5 S)-27$

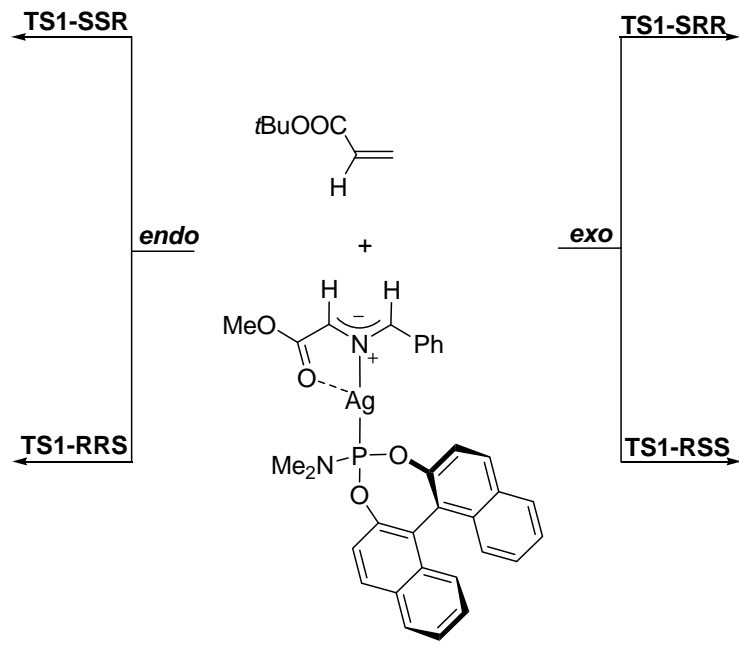

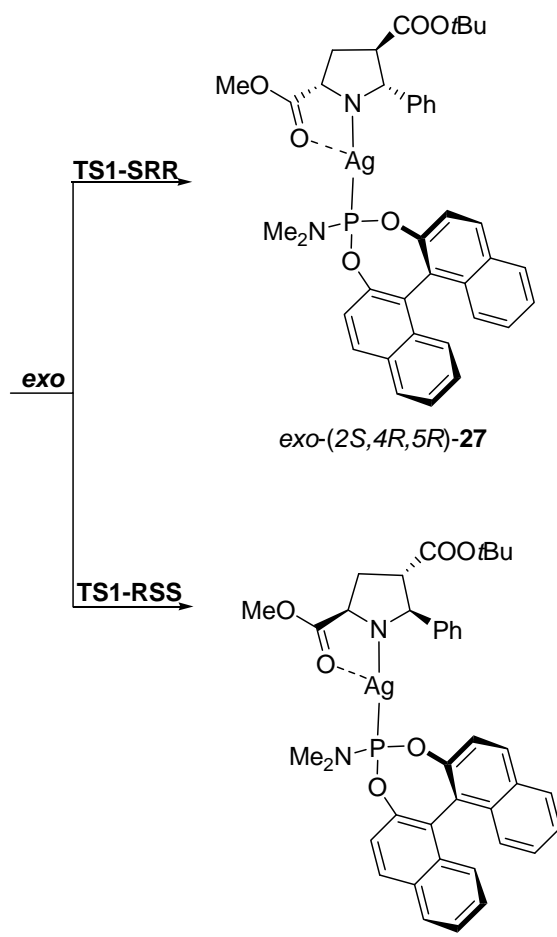

exo-(2R,4S,5S)-27

Scheme 5.
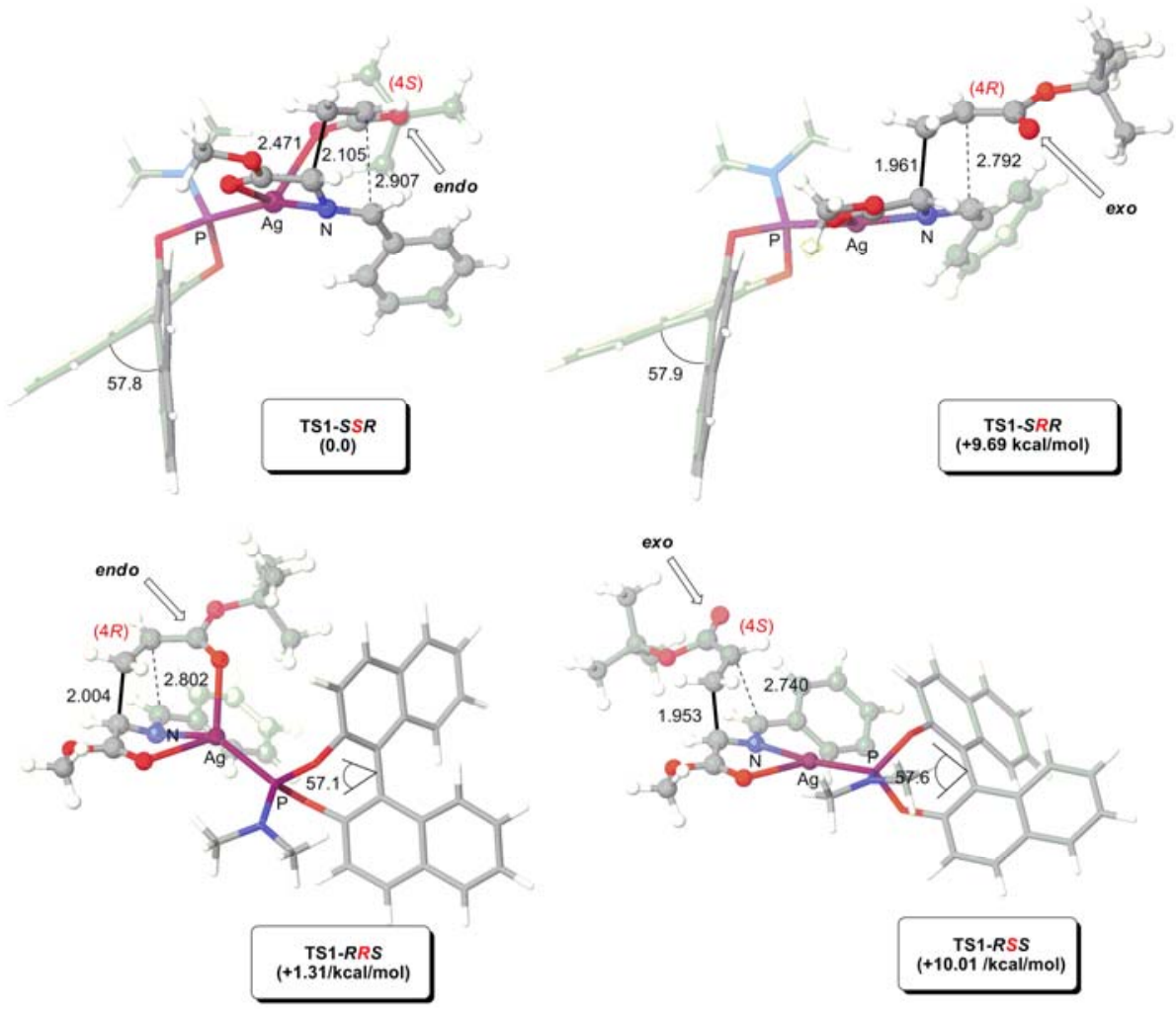

Figure 4. Chief geometric features saddle relative energies (in $\mathrm{kcal} / \mathrm{mol}$ ) of the four transition structures associated with the first step in the reaction between $t$-butyl acrylate and complex II formed by $\left(S_{\mathrm{a}}\right)$-Monophos $\mathbf{1}$ and imine 4aa. Bond distances and angles are given in $\AA$ and $\mathrm{deg}$, respectively. These fully optimized structures were computed at the B3LYP/LanL2DZ\&6-31G* level. The energies were computed at the B3LYP/ LanL2DZ \&6-31G*+ 

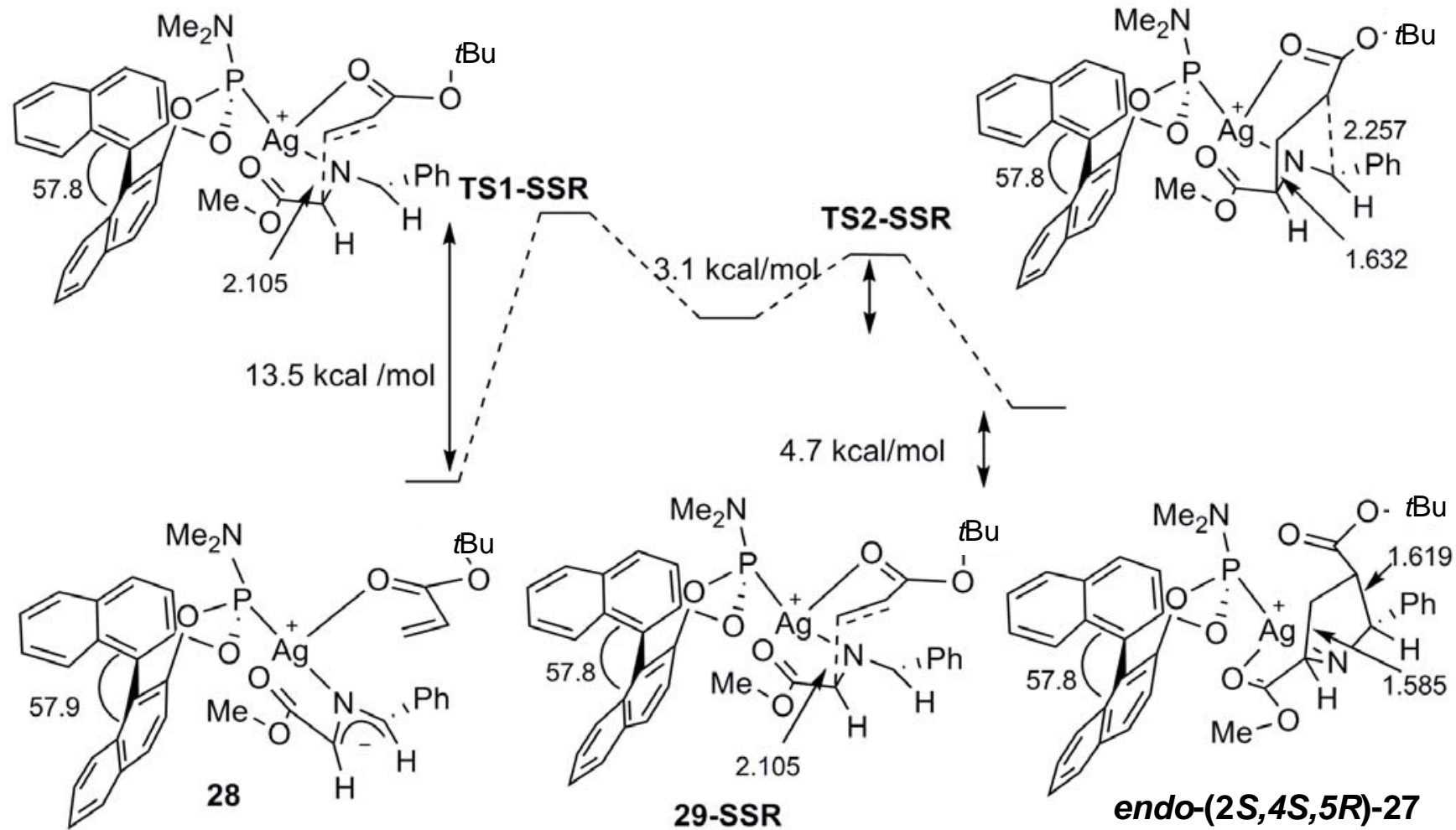

Figure 5. Reaction coordinate associated with the reaction between tert-butyl acrylate and complex II. Bond distances and angles are given in $\AA$ and deg, respectively. The relative energies have been computed at the B3LYP/LanL2DZ\&6-31G*+ 2 ZPVE level of theory.

\section{References}

[1] For reviews, see: a) C. Nájera, J. M. Sansano, Topics Heterocyclic Chem., Ed. A. Hassner 2008, 12, 117-145; b) L. M. Stanley, M. P. Sibi, Chem. Rev. 2008, 108, 2887-2902; c) M. Álvarez-Corral, M. Muñoz-Dorado, I. Rodríguez-García, Chem. Rev. 2008, 108, 3174-3198; d) M. Naodovic, H. Yamamoto, Chem. Rev. 2008, 108, 3132-3148; e) V. Nair, T. D. Suja, Tetrahedron 2007, 63, 122247-12275; f) G. Pandey, P. Banerjee, S. R. Gadre, Chem. Rev. 2006, 106, 4484-4517; g) T. M. V. D. Pinho e Melo, Eur. J. Org. Chem. 2006, 2873-2888; h) M. Bonin, A. Chauveau, L. Micouin, Synlett 2006, 2349-2363; i) C. Nájera, J. M. Sansano Angew. Chem. 2005, 117, 6428-6432; Angew. Chem. Int. Ed. 2005, 44, 6272-6276; j) S. Husinec, V. Savic, Tetrahedron: Asymmetry 2005, 16, 2047-2061.

[2] For more general reviews of 1,3-dipolar cycloadditions see: a) A. Padwa, S. K. Bur, Tetrahedron 2007, 63, 5341-5378; b) H. Pellisier, Tetrahedron 2007, 63, 3235-3285; c) I. Coldham, R. Hufton, Chem. Rev. 2005, 105, 2765-2809.

[3] a) M. I. Calaza, C. Cativiela, Eur. J. Org. Chem. 2008, 3427-3448; b) C. Nájera, J. M. Sansano, Chem. Rev. 2007, 107, 4273-4303; c) P. Karoyan, S. Sagan, O. Lequin, J. Quancard, S. Lavielle, G. Chassaing Targets Heterocycl. Syst. 2004, 8, 216-273.

[4] S. Pujals, E. Giralt, Adv. Drug. Delivery Rev. 2008, 37, 473-484.

[5] a) C. Nájera, M. G. Retamosa, J. M. Sansano, A. de Cózar, F. P. Cossío, Eur. J. Org. Chem. 2007, 30, 5038-5049; b) G. Burton, T. W. Ku, T. J. Carr, T. Kiesow, J. Lin-Goerke, A. Baker, D. L. Earnshaw, G. A. Hofmann, R. M. Keenan, D. Dhanak, Bioorg. Med. Chem. Lett. 2005, 15, $1553-1556$.

[6] D. J. Wardrop, M. S. Burge, Chem. Commun. 2004, 1230-1231.

[7] a) J. E. Baldwin, A. M. Fryer, G. J. Pritchard, M. R. Spyvee, R. C. Whitehead, M. E. Wood, Tetrahedron 1998, 54, 7465-7484; b) A. F. Parsons, Tetrahedron 1996, 52, 4149-4174.

[8] a) Enantioselective Organocatalysis (Ed: P. I. Dalko), Wiley-VCH, Weinheim, 2007; b) Asymmetric Organocatalysis: from Biomimetic Concepts to Applications in Asymmetric Synthesis, (Eds: A. Berkessel, H. Gröger), Wiley-VCH, Weinheim, 2005.

[9] a) P. Allway, R. Grigg, Tetrahedron Lett. 1991, 32, 5817-5820; b) R. Grigg, Tetrahedron: Asymmetry 1995, 6, 2475-2486.

[10] J. M. Longmire, B. Wang, X. Zhang, J. Am. Chem. Soc. 2002, 124, 13400-13401.

[11] a) S. B. Yu, X.-P. Hu, J. Deng, D.-Y. Wang, Z.-C. Duan, Z. Zheng, Tetrahedron: Asymmetry 2009, 20, 621-625; b) C. Nájera, M. G. Retamosa, J. M. Sansano, A. de Cózar, F. P. Cossío, Tetrahedron: Asymmetry 2008, 19, 2913-2923; c) C. Nájera, M. G. Retamosa, J. M. Sansano, Angew. Chem. 2008, 120, 6144-6147; Angew. Chem. Int. Ed. 2008, 47, 6055-6058; d) C. Nájera, M. G. Retamosa, J. M. Sansano, Org. Lett. 2007, 9, 4025-4028; e) W. Zheng, G.-Y Chen, Y. G. Zhou, Y.-X. Li, J. Am. Chem. Soc. 2007, 129, 750-751; f) W. Zheng,Y.-G- Zhou, Tetrahedron Lett. 2007, 48, 4619-4622; g) R. Stohler, F. Wahl, A. Pfaltz, Synthesis 2005, 1431-1436; h) W. Zheng, Y.-G. Zhou, Org. Lett. 2005, 7, 5055-5058; i) T. F. Knöpfel, P. Aschwanden, T. Ichikawa, T. Watanabe, E. M. Carreira, Angew. Chem. 2004, 116, 6097-6099; Angew. Chem. Int. Ed. 2004, 43, 5971-5973; j) C. Chen, X. Li, S. L. Schreiber, J. Am. Chem. Soc. 2003, 125, 10174-10175.

[12] a) A. López-Pérez, J. Adrio, J. C. Carretero, Angew. Chem. 2009, 121, 346-349; Angew. Chem. Int. Ed. 2009, 48, 340-343; b) J. Hernández-Toribio, R. Gómez-Arrayás, B. Martín-Matute, J. C. Carretero, Org. Lett. 2009, 11, 393-396; c) C.-J. Wang, Z. Y. Xue, G. Liang, Z. Lu, Chem. Commun. 2009, 2905-2907. d) A. López-Pérez, J. Adrio, J. C. Carretero, J. Am. Chem. Soc. 2008, 130, 10084-10085; e) S. Fukuzawa, H. Oki, Org. Lett. 2008, 10, 1747-1750; f) C.-J. Wang, G. Liang, Z.Y. Xue, F. Gao, J. Am. Chem. Soc. 2008, 130, 17250-17251; g) T. Llamas, R. Gómez-Arrayás, J. C. Carretero, Synthesis 2007, 950-957; h) J.-W. Shi, J. W. Shi, Tetrahedron: Asymmetry 2007, 18, 645-650; i) B. Martín-Matute, S. I. Pereira, E. Peña-Cabrera, J. 
Adrio, A. M. S. Silva, J. C. Carretero, Adv. Synth. Catal. 2007, 349, 1714-1724; j) S. Cabrera, R. Gómez-Arrayás, B. Martín-Matute, F. P. Cossío, J. C. Carretero, Tetrahedron 2007, 63, 6587-6602; k) X.-X. Yan, Q. Peng, Y. Zhang, K. Zhang, W. Hong, X.-L. Hou, Y.-D. Wu, Angew Chem. 2006, 118, 2013-2017; Angew. Chem. Int. Ed. 2006, 45, 1979-1983; 1) T. Llamas, R. Gómez-Arrayás, J. C. Carretero, Org. Lett. 2006, 8, 1795-1798; m) W. Gao, X. Zhang, M. Raghunath, Org. Lett. 2005, 7, 4241-4244; n) S. Cabrera, R. Gómez-Arrayás, J. C. Carretero, J. Am. Chem. Soc. 2005, $127,16394-16395$. For copper(II)-catalyzed 1,3-dipolar cycloadditions see: Y. Oderaotoshi, W. Cheng, S. Fujitomi, Y. Kasano, S. Minakata, M. Komatsu, Org. Lett. 2003, $5,5043-5046$.

[13] a) O. Dogan, H. Koyuncu, P. Garner, A. Bulut, W. J. Youngs, M. Panzner, Org. Lett. 2006, 8, 4687-4690; b) A. S. Gothelf, K. V. Gothelf, R. G. Hazell, K. A. Jørgensen, Angew. Chem. 2002, 114, 4410-4412; Angew. Chem. Int. Ed. 2002, 41, 4236-4238.

[14] J.-W. Shi, M.-X. Zhao, Z.-Y. Lei, M. Shi, J. Org. Chem. 2008, 73, 305-308.

[15] a) T. Tsubogo, S. Saito, K. Seki, Y. Yamashita, S. Kobayashi, J. Am. Chem. Soc. 2008, 130, 13321-13332; b) S. Saito, T. Tsubogo, S. Kobayashi, J. Am. Chem. Soc. 2007, 129, 5364-5365.

[16] The employment of organocatalysts has been reported: a) M. Nakano, M. Terada, Synlett 2009, 1670-1674. b) R. C. Flanagan, S. Xie, A. Millar, Org. Process Res. Develop. 2008, 12, 1307-1312; c) A. A. Agbodjan, B. E. Cooley, R. C. B. Copley, J. A. Corfield, R. C. Flanagan, B. N. Glover, R. Guidetti, D. Haigh, P. D. Howes, M. M. Jackson, R. T. Matsuoka, K. J. Medhurst, A. Millar, M. J. Sharp, M. J. Slater, J. F. Toczko, S. Xie, J. Org. Chem. 2008, 73, 3094-3102; d) M.-X. Xue, X.-M. Zhang, L.-Z. Gong, Synlett 2008, 691-694; e) J. L. Vicario, S. Reboredo, D. Badía, L. Carrillo Angew. Chem. 2007, 119, 5260-5262; Angew. Chem. Int. Ed. 2007, 46, 5168-5170; f) I. Ibrahem, R. Ríos, J. Vesely, A. Córdova, Tetrahedron Lett. 2007, 48, 6252-6257; g) S. Arai, F. Takahashi, R. Tsuji, A. Nishida, Heterocycles 2006, 67, 495-501; h) C. Alemparte, G. Blay, K. A. Jørgensen, Org. Lett. 2005, 7, 4569-4572.

[17] C. Nájera, M. G. Retamosa, J. M. Sansano, Spanish patent application: P200800908, 2008.

[18] D. Polet, A. Alexakis, K. Tissot-Croset, C. Corminboeuf, K. Ditrich, Chem. Eur. J. 2006, 12, 3596-3609.

[19] a) A. J. Minnaard, B. L. Feringa, L. Lefort, J. D de Vries, Acc. Chem. Res. 2007, 40, 1267-1277; b) “Comprehensive Asymmetric Catalysis”, Vol., 1-3, Supplements 1-2. (Eds. E. N. Jacobsen, A. Pfaltz, H. Yamamoto). Springer-Verlag, Heidelberg, 2004.

[20] The term endo obeys to the approach of the dipolarophile with its electron-withdrawing group oriented to the metal centre, independently of whether the reaction is concerted at the transition state.

[21] a) D. L. Reger, R. F. Semeniuc, J. D. Elgin, V. Rassolov, M. D. Smith, Cryst. Growth Des. 2006, 6, 2758-2768; b) M.-C. Brandys, R. J. Puddephatt, J. Am. Chem. Soc. 2002, 124, 3946-3950; c) M. Munakata, M. Wen, Y. Suenaga, T. Kuroda-Sowa, M. Maekawa, M. Anahata, Polyhedron 2001, 20, 2037-2043; d) O. Mamula, A. von Zelewsky, T. Bark, G. Bernardinelli, Angew. Chem. 1999, 111, 3129-3133; Angew. Chem. Int. Ed. 1999, 38, 29452948.

[22] a) R. C. Flanangan, S. Xie, A. Millar, Org. Process Res. Dev. 2008, 12, 1307-1312; b) M. J. Slater, E. M. Amphlett, D. M. Andrews, G. Bravi, G. Burton, A. G. Cheasty, J. A. Corfield, M. R. Ellis, R. H. Fenwick, S. Fernandes, R. Guidetti, D. Haigh, C. D. Hartley, P. D. Howes, D. L. Jackson, R. L. Jarvest, V. L. H. Lovegrove, K. J. Medhurst, N. R. Parry, H. Price, P. Shah, O. M. P. Singh, R. Stocker, P. Thommes, C. Wilkinson, A. Wonacott, J. Med. Chem. 2007, 50, 897-900.

[23] a) G. Burton, T. W. Ku, T. J. Karr, T. Kiesow, R. T. Sarisky, J. Lin-Goerke, G. A. Hofmann, M. J. Slater, D. Haig, D. Dhanak, V. K. Johnson, N. R. Parry, P. Thommes, Bioorg. Med. Chem. Lett 2007, 17, 1930-1933; b) G. Burton, T. W. Ku, T. J. Karr, T. Kiesow, R. T. Sarisky, J. Lin-Goerke, A. Baker, D. L. Earnshaw, G. A. Hofmann, R. M. Keenan, D. Dhanak, Bioorg. Med. Chem. Lett 2005, 15, 1553-1556.

[24] a) S. Vivanco, B. Lecea, A. Arrieta, P. Prieto, I. Morao, A. Linden, F. P. Cossío, J. Am. Chem. Soc., 2000, 122, 6078-6092. b) M. Ayerbe, A. Arrieta, F. P. Cossío, J. Org. Chem., 1998, 63, 1795-1805. c) A. Takusawa, K. Kawakate, S. Kanemasa, J. M. Rudzinski, J. Chem. Soc. Perkin Trans 2, 1994, 2525-2530. d) A. Zubía, L. Mendoza, S. Vivanco, E. Aldaba, T. Carrascal, B. Lecea, A. Arrieta, T. Zimmerman, F. Vidal-Vanaclocha, F. P. Cossío, Angew. Chem. Int. Ed., 2005, 44, 2903-2907.

[25] This $\pi$-aromatic silver interaction was observed in the cross-linked sheets formed by $1: 1$ mixture of $\left(S_{\mathrm{a}}, R, R\right)-3: \mathrm{AgClO} 4(\mathrm{see}$ also ref. $[21]$ and supporting information of ref. [11c])

[26] M. J. Frisch, G. W. Trucks, H. B. Schlegel, G. E. Scuseria, M. A. Robb, J. R. Cheeseman, J. A. Montgomery, Jr., T. Vreven, K. N. Kudin, J. C. Burant, J. M. Millam, S. S. Iyengar, J. Tomasi, V. Barone, B. Mennucci, M. Cossi, G. Scalmani, N. Rega, G. A. Petersson, H. Nakatsuji, M. Hada, M. Ehara, K. Toyota, R. Fukuda, J. Hasegawa, M. Ishida, T. Nakajima, Y. Honda, O. Kitao, H. Nakai, M. Klene, X. Li, J. E. Knox, H. P. Hratchian, J. B. Cross, V. Bakken, C. Adamo, J. Jaramillo, R. Gomperts, R. E. Stratmann, O. Yazyev, A. J. Austin, R. Cammi, C. Pomelli, J. W. Ochterski, P. Y. Ayala, K. Morokuma, G. A. Voth, P. Salvador, J. J. Dannenberg, V. G. Zakrzewski, S. Dapprich, A. D. Daniels, M. C. Strain, O. Farkas, D. K. Malick, A. D. Rabuck, K. Raghavachari, J. B. Foresman, J. V. Ortiz, Q. Cui, A. G. Baboul, S. Clifford, J. Cioslowski, B. B. Stefanov, G. Liu, A. Liashenko, P. Piskorz, I. Komaromi, R. L. Martin, D. J. Fox, T. Keith, M. A. Al-Laham, C. Y. Peng, A. Nanayakkara, M. Challacombe, P. M. W. Gill, B. Johnson, W. Chen, M. W. Wong, C. Gonzalez, and J. A. Pople, Gaussian 03, Revision C.02, Gaussian, Inc., Wallingford CT, 2004.

[27] a) A. D. Becke, J. Chem. Phys., 1993, 98, 5648-5650. b) A. D. Becke, Phys. Rev. A, 1998, 38, 3098-3100. c) W. Kohn, A. D. Becke, R. G. Parr, J. Phys. Chem., 1996, 100, 12974-12980. d) C. Lee, W. Yang, R. G. Parr, Phys. Rev. B, 1998, 37, 785-789. e) S. H. Vosko, L. Wilk, M. Nusair, Can. J. Phys., 1980, 58, 1200-1211. f) P. J. Stephens, F. J. Devlin, C. F. Chavalowski, M. J. Frisch, J. Phys. Chem., 1994, 98, 11623-11627.

[28] W. J. Hehre, L. Radom, P. V. R. Schleyer, J. A. Popple, Ab Initio Molecular Orbital Theory, Wiley New York, 1986, p76 and references therein.

[29] P. J. May, W. R. Wadt, J. Chem. Phys., 1985, 82, 299-303.

[30] J. W. McIver, A. K. Komornicki, J. Am. Chem. Soc., 1972, 94, 2625-2633.

[31] Y. Jiang, S. Wu, D. Chen, Y. Ma, G. Liu, Tetrahedron, 1988, 44, 5343-5353. 